\title{
The Stereochemistry of the Addition of Chlorotitanium Enolates of $N$-Acyl Oxazolidin-2-ones to 5- and 6- Membered $N$-Acyliminium Ions
}

\author{
Ronaldo A. Pilli*, Maria Alice Böckelmann and Conceição de Fatima Alves
}

\author{
Instituto de Química, Universidade Estadual de Campinas, CP 6154, 13083-970, Campinas - SP, Brazil
}

\begin{abstract}
A adição estereosseletiva de enolatos de titânio derivados de $N$-aciloxazolidin-2-onas a ions $N$-acilimínios de 5- e 6-membros forneceu pirrolidinas 2-substituídas em proporção diastereoisomérica de moderada a boa (5:1-14:1) enquanto diastereosseletividade inferior foi observada na formação das piperidinas 2-substituídas correspondentes. O curso estereoquímico desta reação mostrou ser modulado pela natureza do ion $N$-acilimínio cíclico (5 ou 6 membros), pela natureza de seu grupo carbamato e do grupo $\mathrm{N}$-acila presente no precursor do enolato. $\mathrm{O}$ modelo $l k$ de aproximação parece ser dirigido pela minimização de interações de natureza nãoligante entre o grupo $\mathrm{N}$-acila do enolato de titânio (IV) e os grupos carbamato e metilênico presentes no ion $N$-acilimínio.
\end{abstract}

The stereoselective addition of chiral and achiral titanium enolates derived from the corresponding $N$-acyl oxazolidin-2-ones to 5- and 6- membered $N$-acyliminium ions afforded 2substituted pyrrolidines in moderate to good diastereoisomeric ratio (5:1 to 14:1) while lower diastereoselection was generally observed in the formation of the corresponding 2-substituted piperidines. The stereochemical outcome was found to be modulated by the nature of the cyclic $\mathrm{N}$-acyliminium ion (5- or 6-membered) and of its carbamate and by the $\mathrm{N}$-acyl group in the enolate precursor. The preferential $l k$ approach seems to be dictated mainly by the minimization of non-bonding interactions between the $N$-acyl group in the chlorotitanium (IV) enolate and the carbamate and methylene groups in the cyclic $\mathrm{N}$-acyliminium ion.

Keywords: oxazolidin-2-ones, titanium (IV) enolates, cyclic $N$-acyliminium ions, 2 -substituted pyrrolidines and piperidines.

\section{Introduction}

The condensation of a carbonyl compound with an amine followed by the addition of a carbon nucleophile to the intermediate iminium species, known as the Mannich reaction, is one of the classical methods for the synthesis of $\beta$-aminocarbonyl compounds and nitrogen-containing heterocycles. The use of preformed iminium salts and carbon nucleophiles such as metal enolates, silyl enol ethers, silyl keteneacetals and enamines has greatly expanded the versatility of this reaction allowing the use of milder reaction conditions and the introduction of elements of regioselective control ${ }^{1}$.

Despite the similarity with the aldol reaction much less is known about the structural features controlling the stereochemical outcome of the addition of prochiral carbon nucleophiles to imines or iminium ions when compared to

\footnotetext{
*e-mail: pilli@iqm.unicamp.br
}

the corresponding addition to aldehydes. Evans and co-workers put forth a topological analysis for the addition of metallic enolates to imines based on the coordination of the nitrogen lone pair to the metallic species giving rise to chelated transition states which may adopt either chairlike or boat-like geometries depending on the interplay of steric and electronic interactions ${ }^{2}$.

The utilization of $\mathrm{N}$-acyliminium ions has attracted much attention particularly in the intramolecular version of the reaction due to their enhanced electrophilic character and the reduced bias towards Grob fragmentation displayed by the corresponding $\beta$-aminocarbonyl derivatives ${ }^{3}$. An open transition state with an antiperiplanar approach of carbon nucleophiles to the electrophilic center of the iminium ion has been proposed ${ }^{4}$.

Inspired by the early work of Fuentes and co-workers who first revealed the feasibility of the addition of boron enolates of chiral oxazolidin-2-ones to chiral 4-acetoxy2-azetidinones ${ }^{5}$ and by the work of Nagao and co-workers 
who described the addition of tin (II) enolates of chiral 3acyl-1,3-thiazolidine-2-thiones to 4-acetoxy-2-azetidinone and 5-acetoxy-2-pyrrolidinone ${ }^{6}$, we were attracted to study the effect of the ring size and the nature of the carbamoyl group of the $\mathrm{N}$-acyliminium ion in the reactivity and stereochemical outcome of the addition of boron and chlorotitanium (IV) enolates of oxazolidin-2-ones to prochiral cyclic $\mathrm{N}$-acyliminium ions expecting that diastereoselection would be attained due to the known facial discrimination displayed by the enolates of oxazolidin-2ones $^{7}$. Additionally, the results were expected to be of potential interest in the asymmetric synthesis of nitrogen heterocycles such as pyrrolizidine, indolizidine and quinolizidine ring systems ${ }^{8}$.

\section{Results and Discussion}

Initially, we investigated the boron enolate addition of achiral oxazolidin-2-one $\mathbf{1}$ to 2-ethoxypyrrolidine 5, prepared by sodium borohydride reduction of an ethanolic solution of the corresponding lactam9. The boron enolate of achiral oxazolidin-2-one $\mathbf{1}$ was generated in $\mathrm{CH}_{2} \mathrm{Cl}_{2}$ at $0{ }^{\circ} \mathrm{C}$ upon treatment with $\mathrm{n}-\mathrm{Bu}_{2} \mathrm{BOTf}$, according to the procedure by Evans and co-workers ${ }^{10}$, followed by the addition of $\mathbf{5}$ (1.0 equiv.) and an additional equivalent of $\mathrm{n}$-Bu ${ }_{2} \mathrm{BOTf}$ at $0{ }^{\circ} \mathrm{C}$. The diastereoisomeric ratio for (+/-)-7:(+/-)-8 was shown to be 13:1 after inspection of the ${ }^{1} \mathrm{H}$ NMR spectrum $\left(300 \mathrm{MHz}, 55{ }^{\circ} \mathrm{C}\right)$ of the crude product which displayed two doublets at $\delta 1.13$ and $\delta 1.18$ ppm for the methyl group at C-1' (Scheme1) ${ }^{11} . N$-Boc-2substituted pyrrolidine (+/-)-7 was isolated in 50\% yield after column chromatography on silica gel. In comparison, the coupling of the $N, O$-silylketeneacetal derived from $\mathrm{N}$ propionyl oxazolidin-2-one 1, prepared in situ through the addition of 1.2 equiv. of TMSOTf and 1.15 equiv. of $\mathrm{Et}_{3} \mathrm{~N}$ in $\mathrm{CH}_{2} \mathrm{Cl}_{2}$ at $0{ }^{\circ} \mathrm{C}$, with 2-ethoxypyrrolidine $\mathbf{5}$ was also carried out but afforded a 2:1 mixture of (+/-)- 7 and $(+/-)-8$, in $45 \%$ yield (Table 1, entries 1 and 2 ).

Much to our surprise, the experimental protocol described above for the addition of the boron enolate derived from $\mathbf{1}$ to 2-ethoxypyrrolidine $\mathbf{5}$ did not provide the corresponding $N$ - Boc- 2- substituted piperidines (+/-)-9:(+/-)-10 when 2-ethoxypiperidine 6 was added to a $\mathrm{CH}_{2} \mathrm{Cl}_{2}$ soln. of the boron enolate of oxazolidin-2-one $\mathbf{1}$, which was recovered in almost quantitative yield, even when the reaction was carried out at room temperature and for longer reaction period. However, the reaction of 2ethoxypiperidine 6 with the $\mathrm{N}, \mathrm{O}$-trimethylsilylketeneacetal of $\mathrm{N}$-propionyl oxazolidin-2-one (1) did proceed to afford a 2:1 mixture of the 2-substituted piperidines corresponding to (+/-)-9 and (+/-)-10, in 36\% non-optimized yield after in situ $N$-Boc deprotection (Table 1, entries 4 and 5).

The same reactivity pattern emerged when we employed the boron enolate derived from chiral oxazolidin-2-one ent2: ${ }^{1} \mathrm{H}$ NMR analysis of the crude mixture revealed that a single 2-substituted pyrrolidine was formed from $\mathbf{5}$ but no reaction was observed with 2-ethoxypiperidine 6 (Scheme 1, Table 1, entries 7 and 8). $N$-Boc pyrrolidine (+)-11 was isolated in 55\% yield after column chromatography on silica gel and had its structure established by X-ray diffraction analysis ${ }^{7 \mathrm{~b}}$.

As we were facing some difficulties reproducing the yields in the reactions with boron enolates ${ }^{12}$, we decided to examine the behavior of the chlorotitanium(IV) enolates of oxazolidin-2-one $\mathbf{1}$ and $\mathbf{2}$ in the presence of cyclic $\mathrm{N}$ acyliminium ions. Upon addition of a $\mathrm{CH}_{2} \mathrm{Cl}_{2}$ soln. of 2ethoxypyrrolidine 5 to a previously formed solution of the chlorotitanium (IV) enolate corresponding to $\mathbf{1}$ in $\mathrm{CH}_{2} \mathrm{Cl}_{2}$ at $-23{ }^{\circ} \mathrm{C}^{7 b}$, a gradual fading of the deep burgundy color of the enolate soln. was observed. ${ }^{1} \mathrm{H}$ NMR analysis (in $\mathrm{CDCl}_{3}$ at $55^{\circ} \mathrm{C}$ ) of the crude product revealed that 2 -substituted pyrrolidines (+/-)-7 and (+/-)-8 were produced in a 14:1

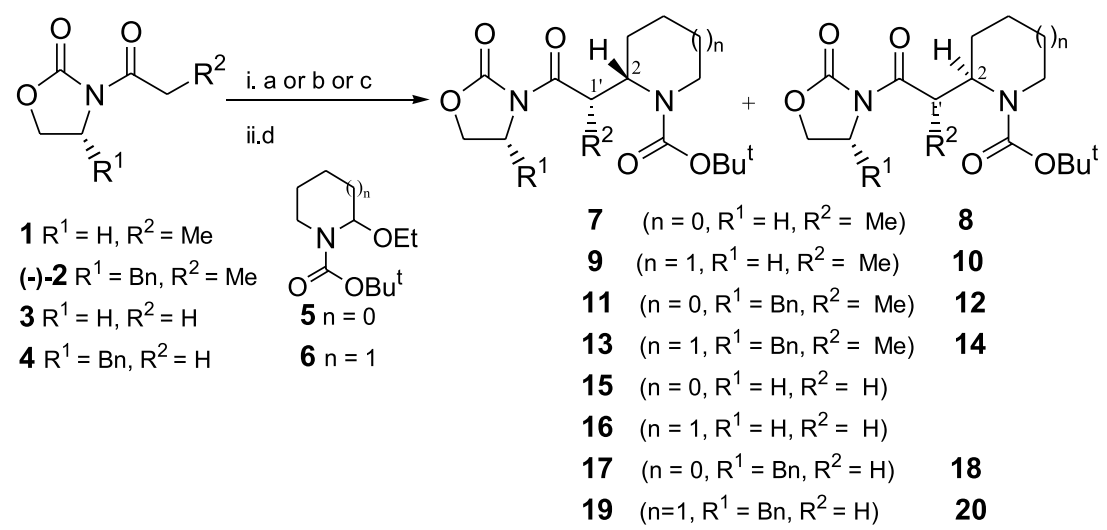

Scheme 1. a) i. ${ }^{\mathrm{n}} \mathrm{Bu}_{2} \mathrm{BOTf}, \mathrm{CH}_{2} \mathrm{Cl}_{2}, 0{ }^{\circ} \mathrm{C}$, ii. DIPEA, 45 min.; b) $\mathrm{Et}_{3} \mathrm{~N}$, TMSOTf, $\mathrm{CH}_{2} \mathrm{Cl}_{2}, 0^{\circ} \mathrm{C}$; c) i $\mathrm{TiCl}_{4}, \mathrm{CH}_{2} \mathrm{Cl}_{2}, 0$ or $-23{ }^{\circ} \mathrm{C}$ ii. DIPEA, $1 \mathrm{~h}$; d) 5 or $\mathbf{6}$, $\mathrm{CH}_{2} \mathrm{Cl}_{2}$. 
Table1.

\begin{tabular}{|c|c|c|c|c|c|c|}
\hline Entry & Substrates $^{\mathrm{a}}$ & Enolization Conditions & $\mathbf{n}, \mathbf{R}_{1}, \mathbf{R}_{2}$ & Product & Ratio $^{\mathbf{b}}$ & Yield $^{\mathrm{f}}$ \\
\hline 1 & $1 / 5$ & $\mathrm{Bu}_{2}^{\mathrm{n}} \mathrm{BOTf}$, DIPEA & $0, \mathrm{H}, \mathrm{Me}$ & $7: 8$ & $13: 1$ & 50 \\
\hline 2 & $1 / 5$ & TMSOTf, $\mathrm{Et}_{3} \mathrm{~N}$ & $0, \mathrm{H}, \mathrm{Me}$ & $7: 8$ & $2: 1$ & 45 \\
\hline 3 & $1 / 5$ & $\mathrm{TiCl}_{4}$, DIPEA & $0, \mathrm{H}, \mathrm{Me}$ & $7: 8$ & $14: 1$ & 72 \\
\hline 4 & $1 / 6$ & $\mathrm{Bu}_{2}^{\mathrm{n}}$ BOTf, DIPEA & $1, \mathrm{H}, \mathrm{Me}$ & $9: 10$ & - & - \\
\hline 5 & $1 / 6$ & TMSOTf, $\mathrm{Et}_{3} \mathrm{~N}$ & $1, \mathrm{H}, \mathrm{Me}$ & 9:10 & $2: 1$ & 36 \\
\hline 6 & $1 / 6$ & $\mathrm{TiCl}_{4}$, DIPEA & $1, \mathrm{H}, \mathrm{Me}$ & 9:10 & - & - \\
\hline 7 & $(+)-2 / 5$ & $\mathrm{Bu}_{2}^{\mathrm{n}} \mathrm{BOTf}$, DIPEA & $0, \mathrm{Bn}, \mathrm{Me}$ & ent-11:12 & $>95: 5^{\mathrm{c}}$ & 55 \\
\hline 8 & $(-)-2 / 5$ & $\mathrm{TiCl}_{4}$, DIPEA & $0, \mathrm{Bn}, \mathrm{Me}$ & 11:12 & $9: 1^{\mathrm{d}, \mathrm{e}}$ & 85 \\
\hline 9 & $(+)-2 / 6$ & $\mathrm{Bu}_{2}^{\mathrm{n}} \mathrm{BOTf}, \mathrm{DIPEA}$ & $1, \mathrm{Bn}, \mathrm{Me}$ & ent-13:14 & - & - \\
\hline 10 & $3 / 5$ & $\mathrm{TiCl}_{4}$, DIPEA & $0, \mathrm{H}, \mathrm{H}$ & 15 & - & 46 \\
\hline 11 & $3 / 6$ & $\mathrm{TiCl}_{4}^{4}$, DIPEA & $1, \mathrm{H}, \mathrm{H}$ & 16 & - & 40 \\
\hline 12 & $4 / 5$ & $\mathrm{TiCl}_{4}$, DIPEA & $0, \mathrm{Bn}, \mathrm{H}$ & $17: 18$ & $1: 1^{\mathrm{d}}$ & 70 \\
\hline 13 & $4 / 6$ & $\mathrm{TiCl}_{4}$, DIPEA & $1, \mathrm{Bn}, \mathrm{H}$ & $19: 20$ & $3.5: 1^{\mathrm{e}}$ & 90 \\
\hline
\end{tabular}

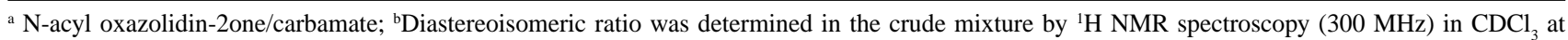
$50^{\circ} \mathrm{C}$; ${ }^{\mathrm{c}}$. Di-n-butyl-boron enolate derived from (+)-2 was employed; ${ }^{\mathrm{d}}$ Diastereoisomeric ratio was determined in the crude mixture by HPLC or GC analysis; ${ }^{\mathrm{e}}$ Diastereoisomers separated by flash chromatography; ${ }^{\mathrm{f}}$ Yields are reported after purification by column chromatography.

ratio (Scheme 1, Table 1, entry 3). Purification by column chromatography on silica gel gave (+/-)-7 in $72 \%$ yield. As before, no reaction took place when 2-ethoxypiperidine 6 was employed at $-23{ }^{\circ} \mathrm{C}$ or at $0{ }^{\circ} \mathrm{C}$ (Table 1 , entry 6 ).

The puzzling behavior of 2-ethoxypiperidine 6 led us to examine the addition of the chlorotitanium (IV) enolate derived from $\mathrm{N}$-acetyl oxazolidin-2-one $\mathbf{3}$ which was expected to relieve steric hindrance during the approach of the nucleophile to the intermediate $\mathrm{N}$-acyliminium ion. In fact, 2-substituted piperidine $\mathbf{1 6}$ was isolated in $40 \%$ yield when the reaction was carried out at $-23^{\circ} \mathrm{C}$ (Scheme 1 ,Table 1, entry 11). Under the same reaction conditions, 5 afforded 2-substituted pyrrolidine $\mathbf{1 5}$ in $46 \%$ yield (Scheme 1 ,Table 1, entry 10). In the chiral series, the reaction of chlorotitanium (IV) enolate derived from (-)-4 with 5 and 6 afforded $N$-2-substituted pyrrolidines 17:18 as a 1:1 mixture and piperidines 19:20 as a 3.5:1 mixture in $70 \%$ and $90 \%$ yield, respectively (Scheme 1 , Table 1 , entries 12 and 13).
At this point, it was evident that the ring size and the nature of nucleofile were modulating the reactivity and the stereochemical outcome of the reaction and an evaluation of the impact of the carbamate group of the $\mathrm{N}$-acyliminium ion on the reaction course seemed in order. The reaction with the chlorotitanium (IV) enolate of achiral oxazolidin2-one 1 proceeded with moderate to good yields with $N$ $\mathrm{Cbz}$ and $\mathrm{N}-\mathrm{CO}_{2} \mathrm{Me}$ pyrrolidines $\mathbf{2 1}$ and $\mathbf{2 3}$ and piperidines 22 and 24, but with good diastereoselection only in the pyrrolidine series (Scheme 2, Table 2, entries 1-4). The same trend was observed when the enolate of chiral oxazolidin-2-one 2 (Scheme 2, Table 2, entries 5-8) was employed and the best diastereoselection was achieved with $N$-Boc-2-ethoxypyrrolidine 5 (table 1 , entries 1 and 4).

The unambiguous assignements of the absolute configuration of the major 2-substituted pyrrolidine (-)$\mathbf{1 1}^{7 \mathrm{~b}}$ and piperidine (-)-35 ${ }^{\mathrm{tb}}$ were achieved after X-ray diffraction analyses. The relative configurations of (+/-)-7 and (+/-)-27 were established as 2SR, 1'SR after their

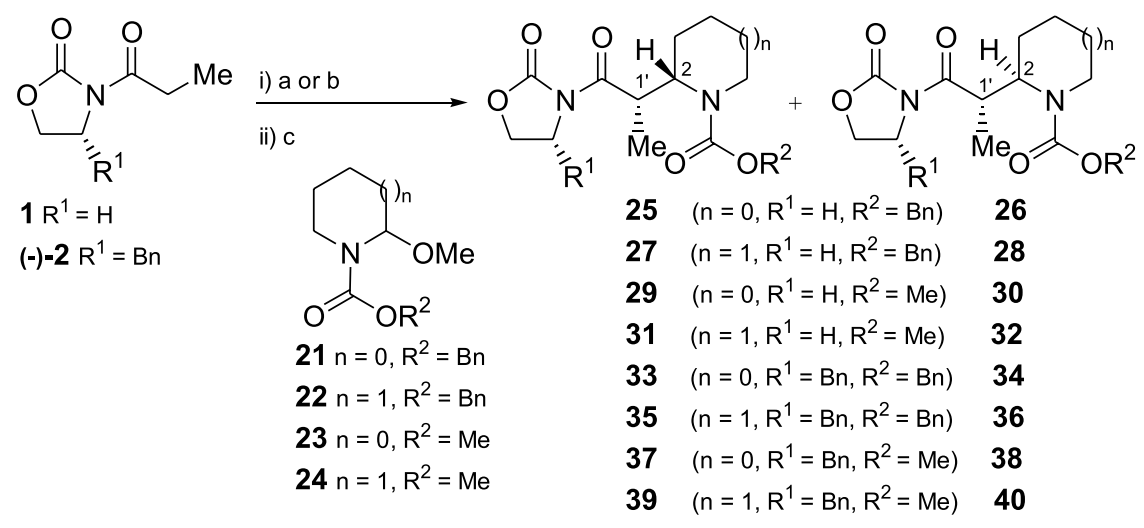

Scheme 2. a) $\mathrm{TiCl}_{4}, \mathrm{CH}_{2} \mathrm{Cl}_{2}, 0{ }^{\circ} \mathrm{C}$, DIPEA; b) $\mathrm{TiCl}_{4}, \mathrm{CH}_{2} \mathrm{Cl}_{2},-23{ }^{\circ} \mathrm{C}$, DIPEA; b) 21-24, $\mathrm{CH}_{2} \mathrm{Cl}_{2}, 0$ or $-23{ }^{\circ} \mathrm{C}$. 
Table 2.

\begin{tabular}{|c|c|c|c|c|c|c|}
\hline Entry & Oxazolidin-2-one & Carbamate & $\mathbf{n}, \mathbf{R}_{1}, \mathbf{R}_{2}$ & Product & Ratio $^{\mathbf{a}}$ & Yield $^{d}$ \\
\hline 1 & 1 & 21 & $0, \mathrm{H}, \mathrm{Bn}$ & $25: 26$ & $10: 1^{b}$ & 67 \\
\hline 2 & 1 & 22 & $1, \mathrm{H}, \mathrm{Bn}$ & 27:28 & $1.6: 1^{\mathrm{b}}$ & 50 \\
\hline 3 & 1 & 23 & $0, \mathrm{H}, \mathrm{Me}$ & 29:30 & $10: 1^{\mathrm{b}}$ & 33 \\
\hline 4 & 1 & 24 & $1, \mathrm{H}, \mathrm{Me}$ & 31:32 & $1.2: 1^{\mathrm{b}, \mathrm{c}}$ & 70 \\
\hline 5 & $(-)-2$ & 21 & $0, \mathrm{Bn}, \mathrm{Bn}$ & 33:34 & $5: 1^{\mathrm{b}}$ & 57 \\
\hline 6 & $(-)-2$ & 22 & $1, \mathrm{Bn}, \mathrm{Bn}$ & $35: 36$ & $1.8: 1^{\mathrm{b}, \mathrm{c}}$ & 50 \\
\hline 7 & $(-)-2$ & 23 & $0, \mathrm{Bn}, \mathrm{Me}$ & $37: 38$ & $6: 1^{b}$ & 50 \\
\hline 8 & $(-)-2$ & 24 & 1, Bn, Me & 39:40 & $1.9: 1^{\mathrm{b}}$ & 61 \\
\hline
\end{tabular}

${ }^{\text {a }}$ Diastereoisomeric ratio was determined in the crude mixture by ${ }^{1} \mathrm{H}$ NMR spectroscopy $(300 \mathrm{MHz})$ in $\mathrm{CDCl}_{3}$ at $50^{\circ} \mathrm{C}$; ${ }^{\mathrm{b}}$ Diastereoisomeric ratio was determined in the crude mixture by HPLC or GC analysis; ${ }^{\mathrm{c}}$ Diastereoisomers separated by flash chromatography; ${ }^{\mathrm{d}}$ Yields are reported after purification by column chromatography.

conversion to the racemic form of carboxylic acids (-)-41 (authentic sample prepared from (-)-11) and $\mathbf{4 2}$ (authentic sample prepared from a 1.8:1 mixture of 35:36), respectively (Scheme 3).

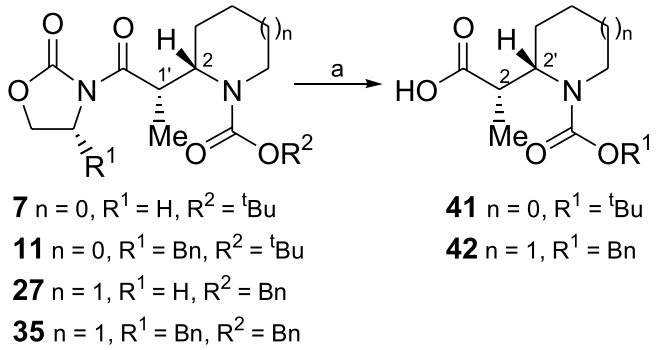

Scheme 3. a) $\mathrm{LiOH}, \mathrm{H}_{2} \mathrm{O}_{2}, \mathrm{THF} / \mathrm{H}_{2} \mathrm{O}, 0{ }^{\circ} \mathrm{C}, 5 \mathrm{~h}$.

The relative configuration of the major products (+/-)25 and (+/-)- 29 formed from achiral oxazolidin-2-one 1 was confirmed to be $2 \mathrm{SR}, 1$ 'SR after conversion of (+/-)- 7 and $(+/-)-25$ to the same pyrrolidine (+/-)-43 which upon carboxymethylation was converted to (+/-)-29 (Scheme 4). The same protocol was employed to correlate 2-substituted piperidines (+/-)-27 and (+/-)-39, after hydrogenolysis and $\mathrm{N}$-carboxymethylation.

The relative configuration $2 \mathrm{RS}, 1$ 'SR of the minor isomer $(+)-\mathbf{1 2}$ formed in the reaction of the chiral chlorotitanium

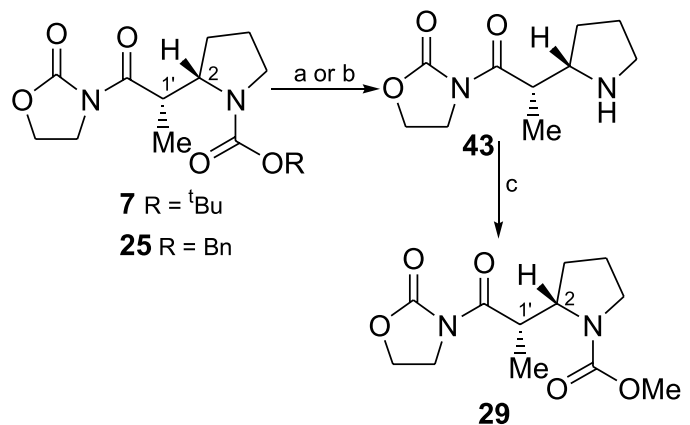

Scheme 4. a) TFA, $\mathrm{CH}_{2} \mathrm{Cl}_{2},{ }^{\circ} \mathrm{C}(50 \%)$; b) $\mathrm{H}_{2}, \mathrm{Pd}-\mathrm{C}, \mathrm{MeOH}(74 \%)$; c) $\mathrm{MeOCOCl}, \mathrm{K}_{2} \mathrm{CO}_{3}$, acetone (70\%).
(IV) enolate derived from $\mathbf{2}$ and 2-ethoxypyrrolidine $\mathbf{5}$ was established after its conversion to carboxylic acid (+)-44 ( $\mathrm{LiOH}, \mathrm{H}_{2} \mathrm{O}_{2}, \mathrm{THF}, \mathrm{H}_{2} \mathrm{O}, 0^{\circ} \mathrm{C}$ ) which proved to be diastereoisomeric to carboxylic acid (-)-41 (Scheme 5). When the major isomer (-)-11 was treated with a THF soln. of LDA at $-78^{\circ} \mathrm{C}$ it underwent partial epimerization at C-1' to afford (-)-45, a diastereoisomer of both the minor isomer (+)-12 and the major isomer (-)-11, together with $N$-acyl urea 46 resulting from the nucleophilic attack of LDA to the endocyclic carbonyl of (-)-11. (Scheme 6).

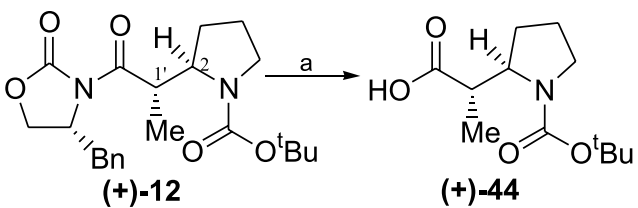

Scheme 5. a) $\mathrm{LiOH}, \mathrm{H}_{2} \mathrm{O}_{2}, \mathrm{THF} / \mathrm{H}_{2} \mathrm{O}, 0{ }^{\circ} \mathrm{C}, 5 \mathrm{~h}(91 \%)$.

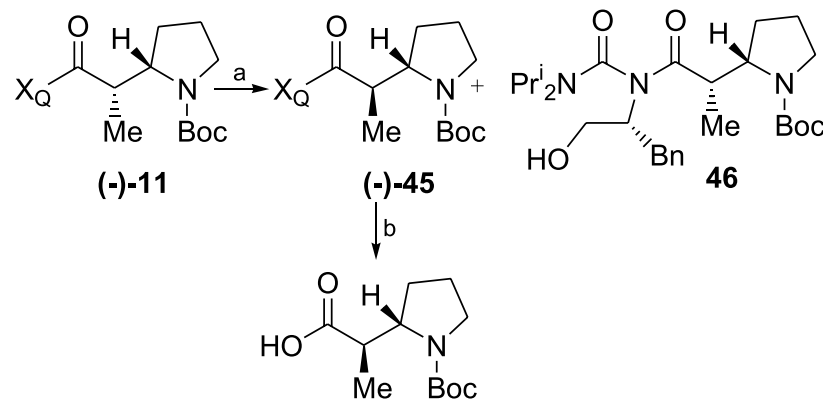
$(-)-44$

Scheme 6. a) LDA, $-78{ }^{\circ} \mathrm{C}(\mathbf{4 5}, 67 \%+\mathbf{4 6}, 33 \%)$; b) $\mathrm{LiOH}, \mathrm{H}_{2} \mathrm{O}_{2}, \mathrm{THF} /$ $\mathrm{H}_{2} \mathrm{O}, 0 \quad{ }^{\circ} \mathrm{C}, 5(91 \%)$

Basic hydrolysis of (-)-45 afforded carboxylic acid (-)44 which was shown to be enantiomeric to the carboxylic acid (+)- $\mathbf{4 4}$ obtained from the basic hydrolysis of (+)-12 thus confirming the $2 \mathrm{R}, 1$ 'S stereochemistry of the later carboxylic acid. (Schemes 5 and 6) 
The absolute configuration of the major and minor pyrrolidines in the mixture 33:34 was assigned after conversion of a 9:1 mixture of 11:12 into a 9:1 mixture of 33:34 which involved Boc removal $\left(\mathrm{CF}_{3} \mathrm{CO}_{2} \mathrm{H}, \mathrm{CH}_{2} \mathrm{Cl}_{2}\right.$, $\mathrm{rt})$ and nitrogen protection $\left(\mathrm{ClCO}_{2} \mathrm{Bn}, \mathrm{K}_{2} \mathrm{CO}_{3}, \mathrm{CH}_{2} \mathrm{Cl}_{2}\right)$. The stereochemistries of pyrrolidines $\mathbf{3 7}$ and $\mathbf{3 8}$ were determined accordingly.

In the piperidine series, X-ray diffraction analysis established the stereochemistry of the major adduct (-)-35 ${ }^{7 \mathrm{~b}}$, and the absolute configuration of the minor isomer (-)-36 was eventually established as $2 \mathrm{R}, 1$ 'S after its conversion to piperidine derivative $(+)-49$, enantiomeric to the piperidine derivative obtained from (-)-35 (Scheme 7).

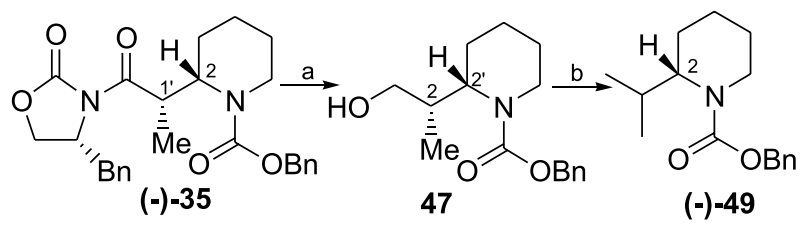

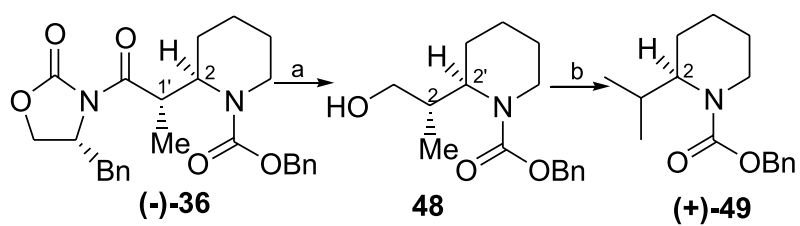

Scheme 7. a) $\mathrm{NaBH}_{4}$, THF, $\mathrm{H}_{2} \mathrm{O}, 16 \mathrm{~h}(70 \%)$; b) i. TsCl, $\mathrm{Et}_{3} \mathrm{~N}$, DMAP (70\%); ii. 1. NaI, DME, $80{ }^{\circ} \mathrm{C} ; 2 .{ }^{n} \mathrm{Bu}_{3} \mathrm{SnH}, 1 \mathrm{~h}(60 \%)$.

Inspection of the ${ }^{13} \mathrm{C}$ NMR spectra in the 2-substituted piperidines series revealed a downfield shift of $\mathrm{C}-2$ in the major isomers when compared with the minor ones $(\Delta \delta$ 1.4-1.7 ppm) which may be diagnostic of their relative stereochemistry. The absolute configuration of 39:40 was confirmed after conversion of a 1.8:1 mixture of (-) -35 and (-)-36 of known configuration to the corresponding mixture of 39:40 (i. $\mathrm{H}_{2}, \mathrm{Pd} / \mathrm{C}, \mathrm{MeOH}$, rt; ii. $\mathrm{MeOCOCl}$, $\mathrm{K}_{2} \mathrm{CO}_{3}$, acetone, $\mathrm{rt}$ ) and comparison by HPLC analysis.
Finally, the major isomer (-)-19 formed in the addition of the chlorotitanium (IV) enolate derived from oxazolidin2-one (-)-4 to 2-ethoxy piperidine 6 was shown to have $2 \mathrm{~S}$ configuration after its conversion to the known methyl ester (-)-51 (Scheme 8) ${ }^{13}$.

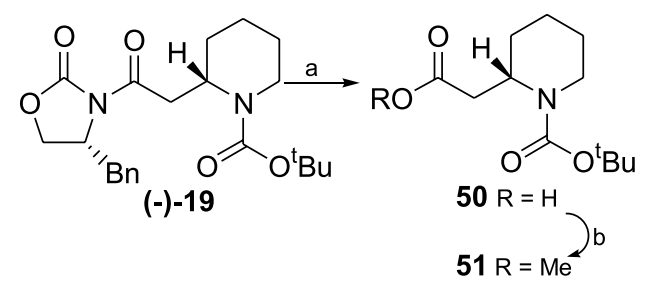

Scheme 8. a) i. $\mathrm{LiOH}, \mathrm{H}_{2} \mathrm{O}_{2}, \mathrm{H}_{2} \mathrm{O}, \mathrm{THF}, 0{ }^{\circ} \mathrm{C}, 5 \mathrm{~h}(85 \%)$; b) $\mathrm{CH}_{2} \mathrm{~N}_{2}, \mathrm{Et}_{2} \mathrm{O}$ $(95 \%)$.

In order to extend the study of the influence of the nature of the nucleophile in the stereochemical outcome of the reaction, chlorotitanium (IV) enolates derived from oxazolidin-2-ones $\mathbf{5 2}$ and $\mathbf{5 3}$ were employed (Scheme 9). Our choice was additionally guided by the potential usefulness of the corresponding adducts in the asymmetric synthesis of (2R, 2'R)-methylphenidate hydrochloride ${ }^{7 \mathrm{c}}$ and in the total synthesis of pyrrolizidine and indolizidine alkaloids ${ }^{6}$.

As depicted in Table 3 the formation of 2-substituted pyrrolidine derivatives occurred with excelent diastereoselection (>95:5, entries 1, 4 and 5) while moderate to good selectivity was observed in the piperidines series (entries 2, 3 and 6), superior to the diastereoisomeric ratio observed with chlorotitanium enolates from oxazolidin-2-ones 1-4 (Table 1 and 2). The absolute configuration for 54, 60 and 62 was tentatively assigned as (2R, 1'R) based on our previous results for the addition of chlorotitanium enolates derived from 2 to $\alpha$-alkoxy pyrrolidines 5, 21 and 23 .

Inspection of the ${ }^{13} \mathrm{C}$ NMR spectra of the mixture $64: 65$ revealed that the major isomer 64 displayed its C-2 shift downfield (1.4 ppm) in comparison with the minor isomer

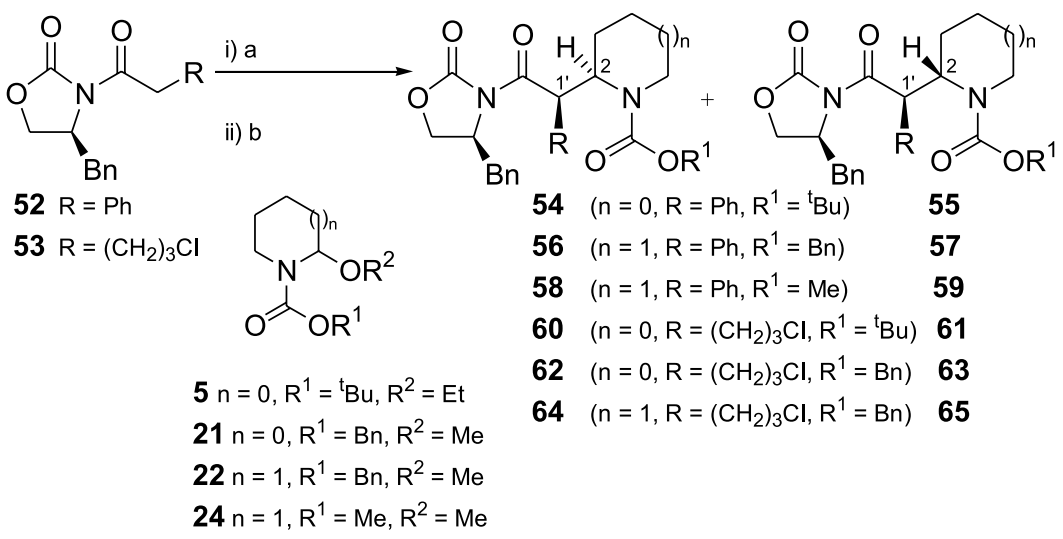

Scheme 9. a) i. $\mathrm{TiCl}_{4}, \mathrm{CH}_{2} \mathrm{Cl}_{2}, 5$ min., $-23{ }^{\circ} \mathrm{C}$; ii. DIPEA, 1h; b) 5, 21, 22 or 24, $\mathrm{CH}_{2} \mathrm{Cl}_{2}$. 
Table 3.

\begin{tabular}{ccccccc}
\hline Entry & Oxazolidin-2-one & Carbamate & $\mathbf{n}, \mathbf{R}, \mathbf{R}^{\mathbf{1}}$ & Products & ratio $^{\text {Yield }(\%)^{\mathbf{b}}}$ \\
\hline 1 & $\mathbf{5 2}$ & $\mathbf{5}$ & $0, \mathrm{Ph},{ }^{\mathrm{b}} \mathrm{Bu}$ & $\mathbf{5 4 : 5 5}$ & $>95: 5^{\mathrm{a}}$ & 70 \\
2 & $\mathbf{5 2}$ & $\mathbf{2 2}$ & $1, \mathrm{Ph}, \mathrm{Bn}$ & $\mathbf{5 6 : 5 7}$ & $12: 1^{\mathrm{a}, \mathrm{c}}$ & 70 \\
3 & $\mathbf{5 2}$ & $\mathbf{2 4}$ & $1, \mathrm{Ph}, \mathrm{Me}$ & $\mathbf{5 8 : 5 9}$ & $8: 1^{\mathrm{a}, \mathrm{e}, \mathrm{e}}$ & 73 \\
4 & $\mathbf{5 3}$ & $\mathbf{5}$ & $0,\left(\mathrm{CH}_{2}\right)_{3} \mathrm{Cl}, \mathrm{Bu}$ & $\mathbf{6 0 : 6 1}$ & $>95: 5^{\mathrm{a}}$ & 81 \\
5 & $\mathbf{5 3}$ & $\mathbf{2 1}$ & $0,\left(\mathrm{CH}_{2}\right)_{3} \mathrm{Cl}, \mathrm{Bn}$ & $\mathbf{6 2 : 6 3}$ & $>95: 5^{\mathrm{a}}$ & 73 \\
6 & $\mathbf{5 3}$ & $\mathbf{2 2}$ & $1,\left(\mathrm{CH}_{2}\right)_{3} \mathrm{Cl}, \mathrm{Bn}$ & $\mathbf{6 4 : 6 5}$ & $4: 1^{\mathrm{b}, \mathrm{f}}$ & 60 \\
\hline
\end{tabular}

${ }^{\text {a }}$ Diastereoisomeric ratio was determined in the crude mixture by ${ }^{1} \mathrm{H}$ NMR spectroscopy $(300 \mathrm{MHz})$ in $\mathrm{CDCl}_{3}$ at $55^{\circ} \mathrm{C}$; ${ }^{\mathrm{b}}$ Yields are reported after purification of the crude mixture by column chromatography; ${ }^{\mathrm{c}}$ Diastereoisomeric ratio was determined in the crude mixture by HPLC analysis; ${ }^{\mathrm{d}}$ Diastereoisomeric ratio was determined in the crude mixture by GC analysis; ${ }^{\text {e }}$ Major diastereoisomer recrystallized from ethyl acetate-hexane; $\mathrm{f}$ Diastereoisomers separated by flash cromatography.

$\mathbf{6 5}$, as observed earlier for 2-substituted piperidines depicted in Table 2. Based on that evidence (2R, 1'R) and ( $\left.2 R, 1^{\prime} S\right)$ configuration were assigned to 64 and 65 , respectively.

The absolute configuration of the majors isomers $\mathbf{5 6}$ and $\mathbf{5 8}$ was established after their conversion to $\left(2 \mathrm{R}, 2^{\prime} \mathrm{R}\right)$ methylphenidate hydrochloride (66). Methylphenidate is a mild psychostimulant and is widely prescribed for the treatment of attention deficit hyperactivity disorder (ADHD) in children, a condition that is manifested by impulsivity, hyperactivity, and inattention. It is marketed as its racemic form despite the fact that the $2 \mathrm{R}, 2^{\prime}$ 'R-isomer is several times more active than the corresponding enantiomer ${ }^{14-16}$.

Basic hydrolysis of the mixture 56/57 allowed the efficient recovery of the chiral auxiliary ( $>90 \%$ yield), and provided carboxylic acid 67 wich was converted to methyl ester 68 in $81 \%$ overall yield, as a 12:1 mixture with its 2'S epimer. Hydrogenolysis followed by treatment with ethanolic $\mathrm{HCl}$, and recrystallization from $\mathrm{EtOH} / \mathrm{Et}_{2} \mathrm{O}$ afforded (+)-(2R, 2'R)-methylphenidate hydrochloride $\mathbf{6 6}$ in $76 \%$ yield from $\mathbf{6 7}$.

Alternatively, basic hydrolysis of $\mathbf{5 8}$ allowed recovery of the chiral auxiliary (90\% yield), and afforded carboxylic acid 69 in $90 \%$ yield. Carbamate deprotection was accomplished with in situ prepared trimethylsilyl iodide and it was followed by esterification and treatment with ethanolic $\mathrm{HCl}$ to provide ( $2 \mathrm{R}, 2$ ' $\mathrm{R})$-methylphenidate hydrochloride 66 in $63 \%$ yield from 69.

Overall, (2R, 2'R)-methylphenidate hydrochloride $\mathbf{6 6}$ was prepared in 4 steps and $43 \%$ overall yield from 22 and in 5 steps and $37 \%$ overall yield from $\mathbf{2 4}$ (Scheme 10).

The absolute configuration ( $\left.2 \mathrm{~S}, 1^{\prime} \mathrm{R}\right)$ for the minors isomers $\mathbf{5 7}$ and $\mathbf{5 9}$ was assigned based on our previous studies (Scheme 2, Table 2) in agreement with the results by Matsumura et $\mathrm{al}^{7 \mathrm{c}}$.

From the body of information described above it emerges that the oxazolidin-2-one moiety is efficiently discriminating its approach to the $\mathrm{N}$-acyliminium ion: in
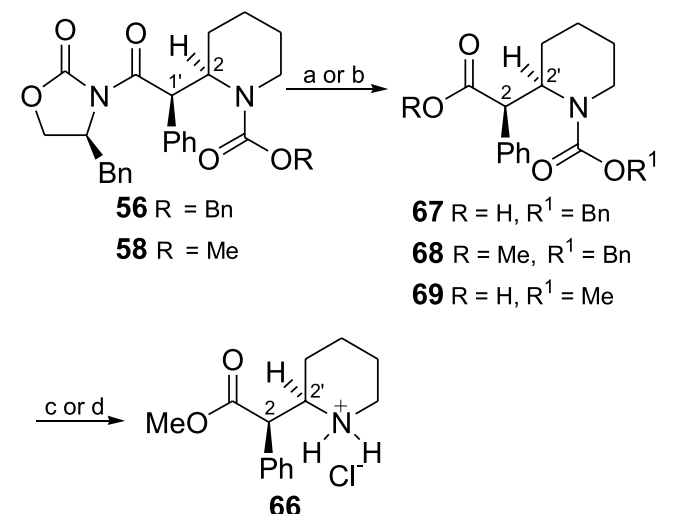

Scheme 10. a) from 56: i. $\mathrm{LiOH}, \mathrm{H}_{2} \mathrm{O}_{2}, \mathrm{THF} / \mathrm{H}_{2} \mathrm{O}, 0^{\circ} \mathrm{C}$; ii. $\mathrm{CH}_{2} \mathrm{~N}_{2}, \mathrm{Et}_{2} \mathrm{O}$, rt (81\%); b) from 58: $\mathrm{LiOH}, \mathrm{H}_{2} \mathrm{O}_{2}, \mathrm{THF} / \mathrm{H}_{2} \mathrm{O}, 0{ }^{\circ} \mathrm{C}(90 \%)$; c) from 68 : i. $\mathrm{Pd}-\mathrm{C}, \mathrm{MeOH}, \mathrm{H}_{2}$; ii. $2 \mathrm{~N} \mathrm{HCl}$, EtOH (76\%, 2 steps); d) from 69: i. $\mathrm{Me}_{3} \mathrm{SiI}$, $\mathrm{CH}_{2} \mathrm{Cl}_{2}, 0{ }^{\circ} \mathrm{C}$; ii. $\mathrm{CH}_{2} \mathrm{~N}_{2}, \mathrm{Et}_{2} \mathrm{O}$, rt; iii. $2 \mathrm{~N} \mathrm{HCl}$, EtOH (63\%, 3 steps)

every case, both major and minor isomers displayed 1'S stereochemistry when (R)-4-benzyl oxazolidin-2-one was employed as chiral auxiliary revealing the preferential approach of the $R e$ face of the corresponding chlorotitanium (IV) enolate. A Z -configured internally coordinated chlorotitanium (IV) enolate, as depicted in Scheme 11, is proposed to be the nucleophilic species in the reactions above and either an antiperiplanar or a synclinal approach of the nucleophile to the $N$-acyliminium ion seems to be available.

For bulky carbamates such as 5-6 (Scheme 1) the stereochemical outcome will be dictated by the relief of steric interactions involving the Boc group: while this seems to be the case for the antiperiplanar approach to $R e$ face of the $N$-acyliminium ion (see A, Scheme 11), the synclinal approach to the $R e$ face of the electrophilic species brings Boc and oxazolidin-2-one groups into close proximity (see B, Scheme 11). Despite keeping Boc and oxazolidin-2one groups apart, the antiperiplanar approach of chlorotitanium (IV) enolate to the $\mathrm{Si}$ face of the $\mathrm{N}$ acyliminium ion develops non-bonding interactions between Boc and $\mathrm{R}_{2}$ groups (see C, Scheme 11). A sterically 


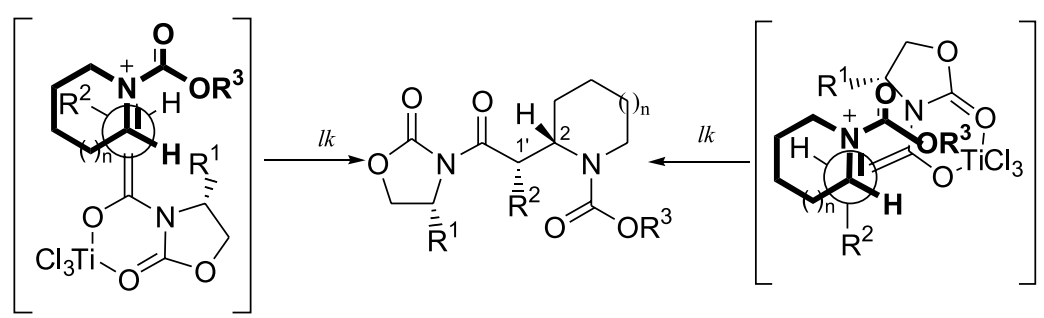

A

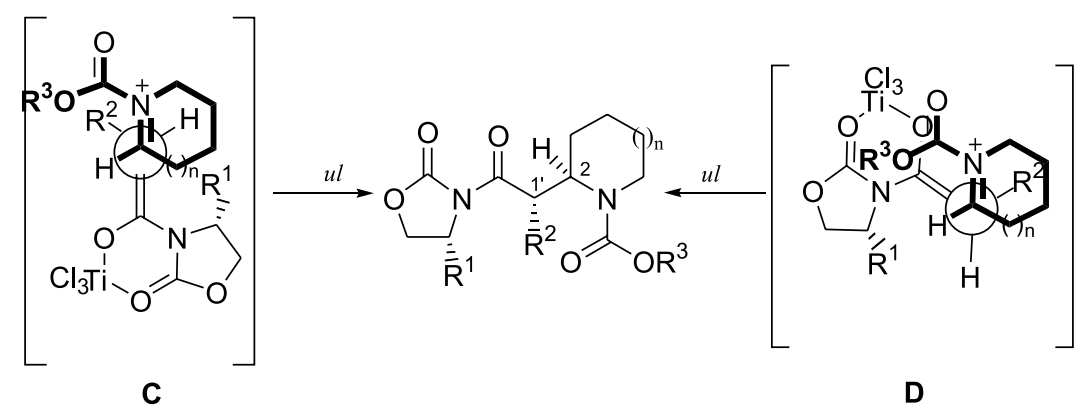

Scheme 11.

congested synclinal approach such as depicted in D (Scheme 11) seems to be of only marginal relevance in the reaction manifold due inter alia to steric hindrance involving the titanium (IV) ligands and Boc group.

The steric interactions involving $\mathrm{R}_{2}$ group and cyclic $\mathrm{N}$-acyliminium ion are not, however, to be overlooked (see A and D, Scheme 11) particularly when cyclic 6-membered $\mathrm{N}$-acyliminium ions are involved. The preferred half-chair conformation in these cases will bring about significant non-bonding interactions during the approach of the nucleophile which are partially relieved when more flattened cyclic 5-membered $\mathrm{N}$-acyliminium ions are involved. Not surprisingly, no reaction was observed between the $N$-acyliminium ion derived from $\mathbf{6}$ and boron enolates prepared from $\mathbf{1}$ and (+)-2 or chlorotitanium (IV) enolates derived from $\mathbf{1}$ and $\mathbf{2}$, even at room temperature and longer reaction periods.

The reactivity was restored when $N$-acyl chlorotitanium (IV) enolates derived from $\mathbf{3}$ and $\mathbf{4}$ were employed in the reaction with $\mathbf{6}$ affording $\mathbf{1 6}$ (40\% yield) and 19:20 (90\% yield, 3.5:1 ratio). The higher diastereoselectivity observed in the reaction of $\mathbf{4}$ and $\mathbf{6}$ (3.5:1 ratio) when compared to the corresponding reaction with 5 (1:1 ratio) may be due to steric hindrance between the half-chair conformation of $\mathbf{6}$ and the oxazolidinone ring thus disfavoring approach $\mathrm{C}$ (Scheme 11).

According to the transition state model depicted in Scheme 11, utilization of less sterically demanding carbamates such as 21-24 resulted in lower levels of diastereoselection when compared to the ones observed for $N$-Boc carbamate 5 while keeping the preference for $l k$ topology ${ }^{17}$. The diastereoisomeric ratios observed for the $\mathrm{N}-\mathrm{CO}_{2} \mathrm{Me}$ and $\mathrm{N}-\mathrm{CO}_{2} \mathrm{Bn}$ 2-alkoxycarbamates did not vary significantly.

The higher levels of diastereoselection observed in the reaction of the chlorotitanium enolate derived from (S)-52 with 22 and $\mathbf{2 4}$ contrasts with those found for (R)-2 and point out either to a relief of steric interaction upon changing a methyl group in the chlorotitanium enolate derived from 2 to a planar, conjugated phenyl ring in the enolate derived from $\mathbf{5 2}$ (A, Scheme 11) or to a synclinal approach as depicted in B (Scheme 11). In both cases, the $l k$ topology ${ }^{17}$ would be greatly favoured resulting in the preferential formation of $\mathbf{5 6}$ and $\mathbf{5 8}$. Additionally the s-cis/ s-trans orientation of the carbamate group and the stereoelectronics associated with 6-membered $\mathrm{N}$ acyliminium ions may be relevant to rationalize these results.

The stereochemical outcome observed in the reaction of the di- $n$-butylboron enolate from ent-2 with 2ethoxypyrrolidine 5 (Scheme 1), which occurred with the same $l k$ topology as observed for the chlorotitanium (IV) enolate from 2, do not support the coordination of the $\mathrm{N}$ acyliminium carbamate group to the Z-configured internally coordinated chlorotitanium (IV) enolate, as proposed by Matsumura and co-workers ${ }^{7 \mathrm{c}}$. 


\section{Conclusions}

The stereochemical outcome of the addition of chlorotitanium (IV) enolates derived from $N$-acyloxazolidin2-ones to in situ generated cyclic $N$-acyliminium ions was shown to be dependent on the nature of the ring size and carbamate group in the $N$-acyliminium ion and on the $N$ acyl group in the chlorotitanium (IV) enolate: 5-membered $\mathrm{N}$-acyliminium ions derived from $\mathbf{5}, \mathbf{2 1}$ and $\mathbf{2 3}$ reacted with the chlorotitanium (IV) enolate derived from $N$-propionyl oxazolidinones $\mathbf{1}$ and $\mathbf{2}$ with moderated to good diastereoisomeric ratio (5:1-14:1) but poor diastereoselection was observed when the $N$-acyliminium ions generated from 6membered piperidines $\mathbf{2 2}$ and $\mathbf{2 4}$ were employed. Better yield and seletivities were observed for the BOC protected $N$ acyliminium ion derived from $\mathbf{5}$ when compared to the corresponding $N$-carbobenzyloxy and $N$-carbomethoxy analogues but $N$-Boc-2-ethoxy piperidine $\mathbf{6}$ failed to react with the chlorotitanium (IV) enolates derived from $\mathbf{1}$ and $\mathbf{2}$.

The preferential $l k$ approach observed was rationalized based on the minimization of steric interactions involving the $N$-acyl group in the chlorotitanium (IV) enolate and carbamate and methylene groups in the cyclic $N$ acyliminium ions.

The reaction of $N$-acyliminium ions derived from $\mathbf{5}$, 22 and $\mathbf{2 4}$ with the chlorotitanium (IV) enolate derived from (S)- $N$-phenylacetyloxazolidinone $\mathbf{5 2}$ provided 2substituted pyrrolidine $\mathbf{5 4}$ (70\% yield, >95:5 d.r.) and 2substituted piperidines $\mathbf{5 6}$ (60\% yield, 12:1 d.r.) and $\mathbf{5 8}$ (73\% yield, 8:1 d.r.) which were converted to (2R, $\left.2^{\prime} \mathrm{R}\right)$ methylphenidate hydrochloride in 4 steps and $62 \%$ and $57 \%$ overall yield, respectively. Studies are underway aiming to employ the adducts obtained from $N$-acyl oxazolidin-2-one $\mathbf{5 3}$ in the asymmetric total synthesis of pyrrolizidine and indolizidine alkaloids.

\section{Experimental Section}

Infrared spectra were recorded on a Nicolet Impact 410 spectrometer and ${ }^{1} \mathrm{H}$ - and ${ }^{13} \mathrm{C}$ NMR spectra were measured on a Bruker AC-300P (7.0T), VARIAN GEMINI (7.0T) or VARIAN INOVA (11.7T) spectrometers. Chemical shifts are reported in parts per million downfield from tetramethylsilane internal standard. Data are reported as follows: chemical shift, integration, multiplicity $(\mathrm{s}=$ singlet, $\mathrm{d}=$ doublet, $\mathrm{t}=$ triplet, $\mathrm{q}=$ quartet, $\mathrm{qt}=$ quintet, $\mathrm{m}=$ multiplet, $\mathrm{br}=$ broad) and coupling constants. Chemical shifts of ${ }^{13} \mathrm{C}$ NMR spectra are reported in ppm from tetramethylsilane using the solvent resonance as internal standard (deuterochloroform: $77.0 \mathrm{ppm}$, deuteromethanol: $49.0 \mathrm{ppm}$ ). NMR data for mixture of diastereoisomers are reported with the chemical shift of the minor diastereoisomer following the one of the major isomer. The optical rotation was measured on a Polamat A (Carl Zeiss) or Perkin Elmer 241 polarimeter. Mass spectra were obtained in the electron impact (EI) mode using an HP-5890-serie II chromatograph equipped with HP1 column $(25 \mathrm{~m} \times 0.20 \mathrm{~mm} \times 0.33 \mu \mathrm{m})$ or Ultra 2 column ( $25 \mathrm{~m} \times 0.20 \mathrm{~mm} \times 0.33 \mu \mathrm{m})$ coupled to a HP-5988 mass detector and high resolution mass spectra on a VG Autospec/ Fission Instrument. HPLC analyses were performed with HP1050 chromatograph equipped with Hypersil column $(5 \mu \mathrm{m}, 200 \times 4,6 \mathrm{~mm})$. Melting points were measured in open capillary tubes using an Electrothermal 9100 apparatus and are not corrected. Elemental analyses were carried on a Perkin Elmer-2400 series II CHNS/O analyser. Column chromatography was performed with Aldrich silica gel (70230 mesh) and flash chromatograph with Merck silica gel 60 (230-400 Mesh). Thin-layer chromatography (TLC) was carried out on Alugram ${ }^{\circledR}$ SIL G/UV ${ }_{254}$ precoated plates and were developed with potassium permanganate in all cases. Unless otherwise noted, all reactions were conducted in flame-dried glassware with magnetic stirring under an inert atmosphere of dry nitrogen or argon. Solvents and reagents were purified and dried when necessary using standard procedures $^{18}$.

\section{Starting Materials}

The achiral $\mathrm{N}$-acyloxazolidinones derivatives $\mathbf{1}$ and $\mathbf{3}^{19}$, the chiral ones $\mathbf{2}, \mathbf{4}, \mathbf{5 2}$ and $\mathbf{5 3}^{20}, \alpha$-ethoxycarbamates $\mathbf{5}$ and $\mathbf{6}^{\mathrm{a}, \mathrm{b}}$ and $\alpha$-methoxycarbamates $\mathbf{2 1 - 2 4 ^ { 2 1 }}$ were prepared according to published procedures.

General procedure for the addition of the N,O-silylketeneacetal from 1 to cyclic $N$-acyliminum ions

To a solution of $\mathbf{1}(0.090 \mathrm{~g}, 0.62 \mathrm{mmol})$ in $\mathrm{CH}_{2} \mathrm{Cl}_{2}(3.0$ $\left.\mathrm{cm}^{3}\right)$ at $0{ }^{\circ} \mathrm{C}$ was added $\mathrm{Et}_{3} \mathrm{~N}\left(0.12 \mathrm{~cm}^{3}, 0.87 \mathrm{mmol}\right)$, and TMSOTf $\left(0.14 \mathrm{~cm}^{3}, 0.74 \mathrm{mmol}\right)$ dropwise. The resulting homogeneous solution was stirred for $45 \mathrm{~min}$ at $0{ }^{\circ} \mathrm{C}$. The solution was cooled to $-78^{\circ} \mathrm{C}$, and the $\alpha$-alkoxycarbamate 5 or $6(0.57 \mathrm{mmol})$ was added, followed by catalytic amount of TMSOTf. After $2 \mathrm{~h}$ the reaction was quenched with satd. aq. $\mathrm{NH}_{4} \mathrm{Cl}\left(5.0 \mathrm{~cm}^{3}\right)$ and extracted with $\mathrm{CH}_{2} \mathrm{Cl}_{2}\left(3 \times 5 \mathrm{~cm}^{3}\right)$. The combined organic layer was dried over $\mathrm{MgSO}_{4}$, filtered and the solvent was evaporated under reduced pressure.

(2SR, I'SR) and (2RS, I'SR) tert-Butyl 2-[2'- (2- oxo- 1,3oxazolan-3-yl)-1'- methyl-2'-oxoethyl\}-1-azolanecarboxylate (7/8)

The product was purified by chromatography on silica 
gel (impregnated with $\mathrm{Et}_{3} \mathrm{~N}, 20 \%$ ethyl acetate-hexane) to provide a $2: 1$ mixture of 7:8 $(0.087 \mathrm{~g}, 45 \%$; determined by ${ }^{1} \mathrm{H}$ NMR analysis) as a colorless solid. IR $v_{\max } / \mathrm{cm}^{-1} 1778$, 1699; ${ }^{1} \mathrm{H} \mathrm{NMR}\left(300 \mathrm{MHz} ; 60{ }^{\circ} \mathrm{C} ; \mathrm{CDCl}_{3}\right) \delta 1.13$ and 1.18 (d, $J 6.7$ and $7.0 \mathrm{~Hz}$, respectively, $3 \mathrm{H}), 1.43$ and 1.44 (s, 9H), 1.55-2.00 (m, 4H), 3.21-3.31 (m, 1H), 3.42-3.52 (m, $1 \mathrm{H}), 3.98-4.09$ (m, 3H), 4.09-4.20 (m, 1H), 4.25-4.40 (m, $2 \mathrm{H}) ;{ }^{13} \mathrm{C}$ NMR $\left(75.5 \mathrm{MHz} ; 60{ }^{\circ} \mathrm{C} ; \mathrm{CDCl}_{3}\right) \delta 13.4,23.5$, 28.4 and 28.5, 28.9, 40.0 and 41.0, 43.1, 47.0, 60.5 and 59.5, 61.7, 79.3, 153.3, 154.9 and 155.0, 175.4; MS (EI): $\mathrm{m} / \mathrm{z} 211(25 \%), 195(7 \%), 170(10 \%), 143(9 \%), 124(24 \%)$, 115 (6\%), 114 (48\%), 88 (17\%), 70 (100\%), 69 (10\%), 57 (82\%); HRMS (EI): found 312.1688; calc. for $\mathrm{C}_{15} \mathrm{H}_{24} \mathrm{~N}_{2} \mathrm{O}_{5}$ $[\mathrm{M}]^{+} 312.1685$.

(2SR, 1'SR) and (2RS, 1'SR) - 2- [2'- (2- oxo- 1,3- oxazolan3-yl)- 1'- methyl-2'-oxoethyl]-1-piperidine (9/10)

The product was purified by chromatography on silica gel (5\% methanol-chloroform with a few drops of $\left.\mathrm{NH}_{4} \mathrm{OH}\right)$ to provide a 2:1 mixture of the corresponding $N$-deprotected form of 9:10 (0.050 g, 36\%; determined by ${ }^{1} \mathrm{H}$ NMR analysis) as a colorless oil. IR $v_{\max } / \mathrm{cm}^{-1} 3453,1706,1658$; ${ }^{1} \mathrm{H}$ NMR $\left(300 \mathrm{MHz} ; \mathrm{CDCl}_{3}\right) \delta 1.19$ and $1.28(\mathrm{~d}, J 7.3$ and $7.0 \mathrm{~Hz}$, respectively, $3 \mathrm{H}), 1.38-1.58(\mathrm{~m}, 2 \mathrm{H}), 1.58-1.80$ (m, 2H), 1.80-2.05 (m, 2H), 2.60-2.82 (m, 2H), 2.82-3.01 and $3.01-3.18(\mathrm{~m}, 1 \mathrm{H}), 3.25-3.42(\mathrm{~m}, 1 \mathrm{H}), 3.62-3.80(\mathrm{~m}$, $2 \mathrm{H}), 3.92-4.06(\mathrm{~m}, 1 \mathrm{H}), 4.06-4.20(\mathrm{~m}, 1 \mathrm{H}), 4.10-4.22(\mathrm{~m}$, $1 \mathrm{H}) ;{ }^{13} \mathrm{C} \mathrm{NMR}\left(75.5 \mathrm{MHz} ; \mathrm{CDCl}_{3}\right) \delta 10.6$ and 13.6, 23.6 and $24.2,25.7,32.0,41.7$ and 38.7, 43.7, 47.4, 57.8 and 57.2, 62.3, 154.9 and 155.3, 173.1; HRMS (EI): found 227.1400 ; calc. for $\mathrm{C}_{11} \mathrm{H}_{19} \mathrm{~N}_{2} \mathrm{O}_{3}[\mathrm{MH}]^{+} 227.1390$.

General procedure for the addition of the titanium enolates of $N$-acyloxazolidinones to cyclic $N$-acyliminium ions

To a solution of $\mathrm{TiCl}_{4}\left(0.12 \mathrm{~cm}^{3}, 1.1 \mathrm{mmol}\right)$ in $\mathrm{CH}_{2} \mathrm{Cl}_{2}$ $\left(2.0 \mathrm{~cm}^{3}\right)$ at temperature $\mathrm{T} 1$ was added dropwise a solution of $\mathrm{N}$-acyloxazolidinone $(1.0 \mathrm{mmol})$ in $\mathrm{CH}_{2} \mathrm{Cl}_{2}\left(2.8 \mathrm{~cm}^{3}\right)$. After $5 \mathrm{~min}$., diisopropylethylamine $\left(0.20 \mathrm{~cm}^{3}, 1.1 \mathrm{mmol}\right)$ was added and the mixture was stirred $1 \mathrm{~h}$ at temperature $\mathrm{T} 1$. The reaction mixture was cooled to temperature $\mathrm{T} 2$ and a solution of $\alpha$-alkoxycarbamate $(1.1 \mathrm{mmol})$ in $\mathrm{CH}_{2} \mathrm{Cl}_{2}(4.8$ $\mathrm{cm}^{3}$ ) was added dropwise. The mixture was then stirred $1 \mathrm{~h}$ at temperature $\mathrm{T} 2$ and the reaction was quenched with satd. aq. $\mathrm{NH}_{4} \mathrm{Cl}\left(5.0 \mathrm{~cm}^{3}\right)$ and extracted with $\mathrm{CH}_{2} \mathrm{Cl}_{2}\left(3 \times 5 \mathrm{~cm}^{3}\right)$. The combined organic layer was dried over $\mathrm{MgSO}_{4}$, filtered and the solvent was evaporated under reduced pressure.

The reaction temperatures ( $\mathrm{T} 1, \mathrm{~T} 2)$, purification, yield, spectral and analytical data of the adducts prepared are as follows.
(2SR, I'SR) and (2RS, l'SR) tert-Butyl 2- [2'- (2- oxo1,3-oxazolan-3-yl)- 1'- methyl-2'-oxoethyl]- 1azolanecarboxylate (7/8)

Reaction temperatures $\mathrm{T} 1=\mathrm{T} 2=-23{ }^{\circ} \mathrm{C}$. The product was purified by chromatography on silica gel (impregnated with $\mathrm{Et}_{3} \mathrm{~N}, 20 \%$ ethyl acetate-hexane) to provide a 14:1 mixture of 7:8 (0.22 g, 72\%; determined by ${ }^{1} \mathrm{H}$ - NMR analysis) as a colorless solid. Data for 7: mp $57{ }^{\circ} \mathrm{C}$; IR $v_{\max } / \mathrm{cm}^{-1} 1778,1699 ;{ }^{1} \mathrm{H} \mathrm{NMR}\left(300 \mathrm{MHz} ; 60{ }^{\circ} \mathrm{C} ; \mathrm{CDCl}_{3}\right)$ $\delta 1.13(\mathrm{~d}, J 6.7 \mathrm{~Hz}, 3 \mathrm{H}), 1.43(\mathrm{~s}, 9 \mathrm{H}), 1.70-2.00(\mathrm{~m}, 4 \mathrm{H})$, 3.21-3.31 (m, 1H), 3.42-3.52 (m, 1H), 3.98-4.09 (m, 3H), 4.09-4.20 (m, 1H), 4.25-4.40 (m, 2H); ${ }^{13} \mathrm{C}$ NMR (75.5 $\left.\mathrm{MHz} ; 60{ }^{\circ} \mathrm{C} ; \mathrm{CDCl}_{3}\right): \delta 13.4,23.5,28.4,28.9,40.0,43.1$, 47.0, 60.5, 61.7, 79.3, 153.3, 154.9, 175.4; MS (EI): $\mathrm{m} / z$ 211 (25\%), 195 (7\%), 170 (10\%), 143 (9\%), 124 (24\%), 115 (6\%), 114 (48\%), 88 (17\%), 70 (100\%), 69 (10\%), 57 (82\%); HRMS (EI): found 312.1688; calc. for $\mathrm{C}_{15} \mathrm{H}_{24} \mathrm{~N}_{2} \mathrm{O}_{5}$ $[\mathrm{M}]^{+} 312.1685$.

(2S, I'S) and (2R, l'S) tert-Butyl 2-\{2'-[(4R)- 4- benzyl2-oxo-1,3-oxazolan-3-yl]- 1'- methyl-2'- oxoethyl\}- 1azolanecarboxylate (11/12)

Reaction temperatures $\mathrm{T} 1=0{ }^{\circ} \mathrm{C}, \mathrm{T} 2=-23{ }^{\circ} \mathrm{C}$. The product was purified by chromatography on silica gel (impregnated with $\mathrm{Et}_{3} \mathrm{~N}, 20 \%$ ethyl acetate-hexane) to afford a 9:1 mixture of $\mathbf{1 1}$ and $\mathbf{1 2}(0.34 \mathrm{~g}, 85 \%$; determined HPLC and ${ }^{1} \mathrm{H}$ NMR analysis) as an oil. The isomers were separated by flash chromatography on silica gel (impregnated with $\mathrm{Et}_{3} \mathrm{~N}, 12 \%$ ethyl acetate-hexane). Found: C, 65.81; H, 7.45; N 7.06. Calc. for $\mathrm{C}_{22} \mathrm{H}_{30} \mathrm{~N}_{2} \mathrm{O}_{5} \mathrm{C}, 65.65$; $\mathrm{H}, 7.51$; N,6.96\%. Data for 11: colorless solid; mp 178$179{ }^{\circ} \mathrm{C} ;[\alpha]_{\mathrm{D}}{ }^{20}-40.4$ (c 1.4, $\left.\mathrm{CH}_{2} \mathrm{Cl}_{2}\right)$; IR $v_{\max } / \mathrm{cm}^{-1} 1782$, 1691; ${ }^{1} \mathrm{H}$ NMR $\left(300 \mathrm{MHz} ; 60{ }^{\circ} \mathrm{C} ; \mathrm{CDCl}_{3}\right) \delta 1.13(\mathrm{~d}, 3 \mathrm{H}, J$ $6.5 \mathrm{~Hz}), 1.45$ (s, 9H), 1.77-1.88 (m, 1H), 1.88-1.98 (m, $3 \mathrm{H}), 2.63(\mathrm{dd}, J 10.2$ and $13.4 \mathrm{~Hz}, 1 \mathrm{H}), 3.26-3.32(\mathrm{~m}, 1 \mathrm{H})$, 3.40-3.60 (m, 2H), 4.05-4.20 (m, 2H), 4.20-4.38 (m, 2H), 4.60-4.70 (m, 1H), 7.19-7.35 (m, 5H); ${ }^{13} \mathrm{C}$ NMR $(75.5$ $\left.\mathrm{MHz} ; 60{ }^{\circ} \mathrm{C} ; \mathrm{CDCl}_{3}\right) \delta 12.4,24.0,28.4,28.7,38.3,40.7$, 47.3, 55.8, 58.9, 66.2, 79.6, 127.3, 129.0, 129.4, 136.2, 154.1, 154.9, 175.5. Data for 12: colorless oil $[\alpha]_{\mathrm{D}}{ }^{20}+0.90$ (c 1.4, $\mathrm{CH}_{2} \mathrm{Cl}_{2}$ ); IR $v_{\max } / \mathrm{cm}^{-1} 1777,1694 ;{ }^{1} \mathrm{H}$ NMR (300 $\left.\mathrm{MHz} ; 50{ }^{\circ} \mathrm{C} ; \mathrm{CDCl}_{3}\right) \delta 1.21(\mathrm{~d}, J 6.6 \mathrm{~Hz}, 3 \mathrm{H}),$,1.47 (s, $9 \mathrm{H}), 1.74-2.12(\mathrm{~m}, 4 \mathrm{H}), 2.69(\mathrm{dd}, J 10.0$ and $13.4,1 \mathrm{H})$, 3.20-3.38 (m, 1H), 3.38-3.62 (m, 2H), 3.92-4.08 (m, 1H), 4.08-4.22 (m, 2H), 4.22-4.42 (br m, 1H), 4.62-4.74 (m, 1H), 7.16-7.40 (m, 5H); ${ }^{13} \mathrm{C}$ NMR $\left(75.5 \mathrm{MHz} ; 50{ }^{\circ} \mathrm{C}\right.$; $\left.\mathrm{CDCl}_{3}\right) \delta 13.9,23.3,28.3,29.7,38.0,41.4,45.7,55.4$, 59.5, 66.1, 79.4, 127.4, 129.1, 129.6, 136.0, 153.5, 155.5, 176.2 . 
tert-Butyl 2- [2'- (2-oxo-1,3-oxazolan-3-yl)-2'-oxoethyl]1- azolanecarboxylate (15)

Reaction temperatures $\mathrm{T} 1=\mathrm{T} 2=-23{ }^{\circ} \mathrm{C}$. The product was purified by chromatography on silica gel (impregnated with $\mathrm{Et}_{3} \mathrm{~N}, 30 \%$ ethyl acetate-hexane) to provide $\mathbf{1 5}(0.14 \mathrm{~g}$, $46 \%)$ as an oil. IR $v_{\text {max }} / \mathrm{cm}^{-1} 1780,1693 ;{ }^{1} \mathrm{H} \mathrm{NMR}(300 \mathrm{MHz}$; $\left.50{ }^{\circ} \mathrm{C} ; \mathrm{CDCl}_{3}\right) \delta 1.44(\mathrm{~s}, 9 \mathrm{H}), 1.60-1.74(\mathrm{~m}, 1 \mathrm{H}), 1.76-1.90$ $(\mathrm{m}, 2 \mathrm{H}), 2.02-2.19(\mathrm{~m}, 1 \mathrm{H}), 3.05(\mathrm{dd}, J 7.8$ and $16.0 \mathrm{~Hz}$, 1H) $3.18-3.42(\mathrm{~m}, 3 \mathrm{H}), 3.94-4.10(\mathrm{~m}, 2 \mathrm{H}), 4.25-4.46(\mathrm{~m}$, $3 \mathrm{H}) ;{ }^{13} \mathrm{C} \mathrm{NMR}\left(75.5 \mathrm{MHz} ; 50{ }^{\circ} \mathrm{C} ; \mathrm{CDCl}_{3}\right) \delta 23.3,28.5,31.6$, 40.0, 42.6, 46.3, 53.9, 62.0, 79.3, 154.4, 154.5, 171.3; MS (EI) $m / z: 243$ (7\%), $242(12 \%), 225(8 \%), 199(6 \%), 198$ (7\%), 197 (63\%), 181 (6\%), $156(7 \%), 154(6 \%), 139(6 \%)$, 127 (5\%), 114 (28\%), 110 (53\%), 101 (5\%), 88 (12\%), 84 (5\%), 83 (15\%), $82(6 \%), 71(6 \%), 70$ (100\%), $69(5 \%), 68$ (7\%), 67 (6\%), 57 (68\%), 56 (6\%), 55 (9\%); HRMS (EI): found 298.1529; calc. for $\mathrm{C}_{14} \mathrm{H}_{22} \mathrm{~N}_{2} \mathrm{O}_{5}[\mathrm{M}]^{+} 298.1529$.

tert-Butyl 2- [2'- (2- oxo- 1,3-oxazolan- 3-yl)- 2'oxoethyl\}-1-piperidinecarboxylate (16)

Reaction temperatures $\mathrm{T} 1=\mathrm{T} 2=-23^{\circ} \mathrm{C}$. The product was purified by chromatography on silica gel (impregnated with $\mathrm{Et}_{3} \mathrm{~N}, 30 \%$ ethyl acetate-hexane) to provide $\mathbf{1 6}(0.12$ $\mathrm{g}, 40 \%)$ as an oil. IR $v_{\max } / \mathrm{cm}^{-1} 1772,1690 ;{ }^{1} \mathrm{H}$ NMR (300 $\left.\mathrm{MHz} ; 60{ }^{\circ} \mathrm{C} ; \mathrm{CDCl}_{3}\right) \delta 1.43(\mathrm{~s}, 9 \mathrm{H}) 1.40-1.70(\mathrm{~m}, 6 \mathrm{H})$, 2.92 (br t, $J 13.1 \mathrm{~Hz}, 1 \mathrm{H}), 3.05$ (dd, $J 9.0$ and $14.0 \mathrm{~Hz}, 1 \mathrm{H}$ ), 3.29 (dd, $J 5.6$ and 14.0, 1H), 3.87-4.03 (m, 3H), 4.30-4.40 $(\mathrm{m}, 2 \mathrm{H}), 4.77-4.85(\mathrm{~m}, 1 \mathrm{H}) ;{ }^{13} \mathrm{C}$ NMR $\left(75.5 \mathrm{MHz} ; 60{ }^{\circ} \mathrm{C}\right.$; $\left.\mathrm{CDCl}_{3}\right) \delta$ 19.2, 25.4, 28.6, 29.3, 35.9, 39.6, 42.7, 47.9, 62.1, 79.4, 153.7, 155.1, 171.2; MS (EI): $\mathrm{m} / \mathrm{z} 211$ (30\%), $184(7 \%), 129(21 \%), 128(69 \%), 124(12 \%), 101(12 \%)$, $88(15 \%), 84$ (100\%), 83 (7\%), 57 (46\%), 55 (7\%); HRMS (EI): found 312.1685; calc. for $\mathrm{C}_{15} \mathrm{H}_{24} \mathrm{~N}_{2} \mathrm{O}_{5}[\mathrm{M}]^{+} 312.1685$.

(2S) and (2R) tert-Butyl 2-\{2'- [(4R)- 4- benzyl-2- oxo- 1,3oxazolan-3-yl]-2'-oxoethyl\}-1-azolanecarboxylate (17/18)

Reaction temperatures $\mathrm{T} 1=0{ }^{\circ} \mathrm{C}$ and $\mathrm{T} 2=-23^{\circ} \mathrm{C}$. The product was purified by chromatography on silica gel (impregnated with $\mathrm{Et}_{3} \mathrm{~N}, 15 \%$ ethyl acetate-hexane) to afford a 1:1 mixture of $\mathbf{1 7}$ and $\mathbf{1 8}(0.27 \mathrm{~g}, 70 \%$; determined by HPLC and ${ }^{1} \mathrm{H}$ NMR analysis) as an oil. IR $v_{\max } / \mathrm{cm}^{-1}$ 1778, 1703; ${ }^{1} \mathrm{H}$ NMR $\left(300 \mathrm{MHz} ; 55^{\circ} \mathrm{C} ; \mathrm{CDCl}_{3}\right) \delta 1.44$ and $1.45\left(9 \mathrm{H}, \mathrm{s}, \mathrm{C}\left(\mathrm{CH}_{3}\right)_{3}\right), 1.59-1.75(\mathrm{~m}, 1 \mathrm{H}), 1.77-2.00$ (m, 2H), 2.00-2.20 (1H, m, CHH-3), 2.77 and $2.76(\mathrm{dd}, J$ 13.5/9.7 and 12.9/9.6 Hz, $1 \mathrm{H}), 2.91-3.08$ and 3.08-3.25 (m, 1H), 3.25-3.45 (m, 4H), 4.10-4.20 (m, 2H), 4.25-4.41 $(\mathrm{m}, 1 \mathrm{H}), 4.58-4.72(\mathrm{~m}, 1 \mathrm{H}), 7.15-7.35(\mathrm{~m}, 5 \mathrm{H}) ;{ }^{13} \mathrm{C}$ NMR $\left(75.5 \mathrm{MHz} ; 60^{\circ} \mathrm{C} ; \mathrm{CDCl}_{3}\right) \delta 23.4$ and 23.1, 28.6, 31.7 and
31.9, 38.2 and 38.3, 40.2 and 40.7, 46.4 and 46.5, 53.8 and 54.2, 55.3 and 55.4, 66.4, 79.4, 127.3, 129.0, 129.5, 135.7, 153.6, 154.5, 171.5 and 171.3; MS (EI): $\mathrm{m} / z 332$ (5\%), 315 (5\%), 288 (13\%), 287 (56\%), 178 (7\%), 156 (8\%), $117(8 \%), 114(22 \%), 110(73 \%), 91(23 \%), 86(6 \%)$, 83 (12\%), 70 (100\%), 68 (9\%), 67 (5\%), 57 (64\%), 55 (7\%); HRMS (EI): found 388.1997; calc. for $\mathrm{C}_{21} \mathrm{H}_{28} \mathrm{~N}_{2} \mathrm{O}_{5}$ $[\mathrm{M}]^{+} 388.1998$.

(2S) and (2R) tert-Butyl 2- \{2'- [(4R)- 4- benzyl-2- oxo1,3-oxazolan- 3-yl]-2'-oxoethyl\}- hexahydro-1pyridinecarboxylate (19/20)

Reaction temperatures $\mathrm{T} 1=\mathrm{T} 2=-23{ }^{\circ} \mathrm{C}$. The product was purified by chromatography on silica gel (30\% ethyl acetate-hexane) to afford a 3.5:1 mixture of $\mathbf{1 9}$ and $\mathbf{2 0}$ ( 0.36 g, 90\%; determined ${ }^{1} \mathrm{H}$ NMR analysis) as an oil. The isomers were separated by flash chromatography on silica gel (15\% ethyl acetate-hexane). MS (EI): $\mathrm{m} / z 219$ (56\%), 149 (21\%), 134 (25\%), 128 (94\%), 124 (31\%), 117 (6\%), 116 (7\%), 92 (17\%), 91 (61\%), 86 (78\%), 84 (100\%), 83 (7\%), 65 (15\%), 57 (59\%); HRMS (EI): found 301.1551; calc. for $\mathrm{C}_{17} \mathrm{H}_{21} \mathrm{~N}_{2} \mathrm{O}_{3}\left[\mathrm{M}-\mathrm{C}_{5} \mathrm{H}_{9} \mathrm{O}_{2}\right]^{+}$301.1552. Data for 19: colorless oil; $[\alpha]_{\mathrm{D}}^{20}-75.0\left(c 1.5, \mathrm{CH}_{2} \mathrm{Cl}_{2}\right) ; \mathrm{IR} v_{\text {max }} / \mathrm{cm}^{-1} 1782$, 1689; ${ }^{1} \mathrm{H}$ NMR (300 MHz; $\left.60{ }^{\circ} \mathrm{C} ; \mathrm{CDCl}_{3}\right) \delta 1.43$ (s, 9H), 1.50-1.74 (m, 6H), $2.77(\mathrm{dd}, J 9.5$ and $13.6 \mathrm{~Hz}, 1 \mathrm{H}), 2.94$ (br t, $J 13.6 \mathrm{~Hz}, 1 \mathrm{H}), 3.07$ (dd, $J 9.2$ and $14.3 \mathrm{~Hz}, 1 \mathrm{H}$ ), $3.29(\mathrm{dd}, J 2.9$ and $15.0 \mathrm{~Hz}, 1 \mathrm{H}), 3.32(\mathrm{dd}, J 5.9$ and 14.3 $\mathrm{Hz}, 1 \mathrm{H}), 3.98$ (br d, $J 15.4 \mathrm{~Hz}, 1 \mathrm{H}$ ), 4.11 (dd, $J 2.9$ and 8.8 $\mathrm{Hz}, 1 \mathrm{H}), 4.22$ (t, J 8.4 Hz, 1H), 4.52-4.64 (m, 1H), 4.78$4.90(\mathrm{~m}, 1 \mathrm{H}), 7.14-7.20(\mathrm{~m}, 2 \mathrm{H}), 7.20-7.34(\mathrm{~m}, 3 \mathrm{H}) ;{ }^{13} \mathrm{C}$ NMR $\left(75.5 \mathrm{MHz} ; 60{ }^{\circ} \mathrm{C} ; \mathrm{CDCl}_{3}\right) \delta 19.1,25.3,28.4,29.1$, $36.2,38.1,39.6,47.7,55.4,66.2,79.3,127.2,128.9,129.3$, 135.6, 153.6, 155.0, 171.0; Data for 20: colorless solid; mp 111.9-112.7 ${ }^{\circ} \mathrm{C} ;[\alpha]_{\mathrm{D}}{ }^{20}-38.3\left(c 1.1, \mathrm{CH}_{2} \mathrm{Cl}_{2}\right)$; IR $v_{\max } / \mathrm{cm}^{-1} 1784,1691 ;{ }^{1} \mathrm{H} \mathrm{NMR}\left(300 \mathrm{MHz} ; 50{ }^{\circ} \mathrm{C} ; \mathrm{CDCl}_{3}\right)$ $\delta 1.43(\mathrm{~s}, 9 \mathrm{H}), 1.50-1.70(\mathrm{~m}, 6 \mathrm{H}), 2.77$ (dd, $J 9.5$ and 13.6 $\mathrm{Hz}, 1 \mathrm{H}$ ), 2.94 (br t, $J 13.0 \mathrm{~Hz}, 1 \mathrm{H}$ ), 3.07 (dd, $J 9.5$ and $13.7 \mathrm{~Hz}, 1 \mathrm{H}), 3.32(\mathrm{dd}, J 2.9$ and $13.6 \mathrm{~Hz}, 1 \mathrm{H}), 3.33(\mathrm{dd}, J$ 5.7 and $14.3 \mathrm{~Hz}, 1 \mathrm{H}), 3.98$ (br d, $J 14.3 \mathrm{~Hz}, 1 \mathrm{H}), 4.11(\mathrm{dd}$, $J 2.8$ and $9.0 \mathrm{~Hz}, 1 \mathrm{H}$ ), 4.22 (br t, $J 8.3 \mathrm{~Hz}, 1 \mathrm{H}$ ), $4.52-4.62$ $(\mathrm{m}, 1 \mathrm{H}), 4.76-4.90(\mathrm{~m}, 1 \mathrm{H}), 7.14-7.20(\mathrm{~m}, 2 \mathrm{H}), 7.20-7.34$ (m, 3H); ${ }^{13} \mathrm{C} \mathrm{NMR}\left(75.5 \mathrm{MHz} ; 50{ }^{\circ} \mathrm{C} ; \mathrm{CDCl}_{3}\right) \delta 19.1,25.3$, 28.4, 29.0, 36.2, 38.1, 39.6, 47.6, 55.4, 66.2, 79.3, 127.2, 128.9, 129.3, 135.6, 153.7, 155.0, 171.0.

(2SR, I'SR) and (2RS, I'SR) Benzyl 2- [2'- (2- oxo- 1,3oxazolan-3-yl)- 1'- methyl-2'- oxoethyl]-1-azolanecarboxylate (25/26)

Reaction temperatures $\mathrm{T} 1=\mathrm{T} 2=-23{ }^{\circ} \mathrm{C}$. The product was purified by chromatography on silica gel (impregnated 
with $\mathrm{Et}_{3} \mathrm{~N}, 30 \%$ ethyl acetate-hexane) to afford a 10:1 mixture of 25 and $26(0.23 \mathrm{~g}, 67 \%$; determined by HPLC analysis) as an oil. Found: $\mathrm{C}, 62.47 ; \mathrm{H}, 6.00 ; \mathrm{N}, 8.17$. Calc. for $\mathrm{C}_{18} \mathrm{H}_{22} \mathrm{~N}_{2} \mathrm{O}_{5} \mathrm{C}, 62.42 ; \mathrm{H}, 6.40 ; \mathrm{N}, 8.09 \%$. IR $v_{\max } / \mathrm{cm}^{-1}$ 1777, 1700; Data for 25: ${ }^{1} \mathrm{H}$ NMR $\left(300 \mathrm{MHz}\right.$; $5{ }^{\circ} \mathrm{C}$; $\left.\mathrm{CDCl}_{3}\right) \delta 1.11(\mathrm{~d}, J 6.2 \mathrm{~Hz}, 3 \mathrm{H}), 1.74-1.86(\mathrm{~m}, 1 \mathrm{H}), 1.86-$ $2.04(\mathrm{~m}, 3 \mathrm{H}), 3.30-3.42(\mathrm{~m}, 1 \mathrm{H}), 3.42-3.54(\mathrm{~m}, 1 \mathrm{H}), 3.64-$ $3.78(\mathrm{~m}, 1 \mathrm{H}), 3.87$ (qt, $J 9.0 \mathrm{~Hz}, 1 \mathrm{H}), 3.90-4.03(\mathrm{~m}, 1 \mathrm{H}$, $\mathrm{CH}-2), 4.04-4.14(\mathrm{~m}, 2 \mathrm{H}), 4.14-4.28(\mathrm{~m}, 1 \mathrm{H}), 5.03(\mathrm{~d}, J$ $12.5 \mathrm{~Hz}, 1 \mathrm{H}), 5.11(\mathrm{~d}, J 12.5 \mathrm{~Hz}, 1 \mathrm{H}), 7.22-7.40(\mathrm{~m}, 5 \mathrm{H})$; ${ }^{13} \mathrm{C}$ NMR $\left(75.5 \mathrm{MHz} ; 55{ }^{\circ} \mathrm{C} ; \mathrm{CDCl}_{3}\right) \delta 13.2,23.3,28.7$, $39.8,42.9,46.9,60.4,61.6,66.6,127.9,128.0,128.4$, 137.1, 153.4, 155.3, 175.3.

(2SR, I'SR) and (2RS, I'SR) Benzyl 2-[2'- (2- oxo- 1,3oxazolan-3-yl)- 1'- methyl- 2'-oxoethyl]- 1-piperidinecarboxylate $(27 / 28)$

Reaction temperatures $\mathrm{T} 1=\mathrm{T} 2=-23{ }^{\circ} \mathrm{C}$. The product was purified by chromatography on silica gel (impregnated with $\mathrm{Et}_{3} \mathrm{~N}, 30 \%$ ethyl acetate-hexane) to afford a 1.6:1 mixture of $\mathbf{2 7}$ and $\mathbf{2 8}(0.18 \mathrm{~g}, 50 \%$; determined by HPLC and ${ }^{1} \mathrm{H}$ NMR analysis) as an oil. IR $v_{\max } / \mathrm{cm}^{-1} 1778,1699$; ${ }^{1} \mathrm{H}$ NMR $\left(300 \mathrm{MHz} ; 60{ }^{\circ} \mathrm{C} ; \mathrm{CDCl}_{3}\right) \delta 1.08$ and $1.01(\mathrm{~d}, J$ 6.6 and $7.0 \mathrm{~Hz}$, respectively; $3 \mathrm{H}), 1.24-1.43(\mathrm{~m}, 1 \mathrm{H}), 1.43-$ $1.62(\mathrm{~m}, 4 \mathrm{H}), 1.68-1.80(\mathrm{~m}, 1 \mathrm{H}), 2.95$ and 2.69 (br t, $J$ 13.0 and $12.6 \mathrm{~Hz}$, respectively; $1 \mathrm{H}$ ), 3.67 and 3.63 (dd, $J$ 5.9 and $9.0 \mathrm{~Hz}, 1 \mathrm{H}), 3.81$ and $3.84(\mathrm{dd}, J 8.1 / 11.0$ and $7.3 /$ $11.0 \mathrm{~Hz}$, respectively; $1 \mathrm{H}), 3.88-4.01(\mathrm{~m}, 1 \mathrm{H}), 4.05-4.15$ (m, 1H), 4.20 and 4.30-4.40 (dt and $\mathrm{m}, J 6.0$ and $8.9 \mathrm{~Hz}$, $1 \mathrm{H}), 4.29(\mathrm{t}, \mathrm{br}, J 8.0 \mathrm{~Hz}, 1 \mathrm{H}), 4.47-4.58$ and $4.61-4.70$ $(\mathrm{m}, 1 \mathrm{H}), 5.00 / 5.06$ and $5.08(\mathrm{~d} / \mathrm{d}$ and s, respectively, $J 12.5$ $\mathrm{Hz}, 2 \mathrm{H}), 7.10-7.50$ (m, 5H); ${ }^{13} \mathrm{C} \mathrm{NMR}\left(75.5 \mathrm{MHz} ; 60{ }^{\circ} \mathrm{C}\right.$; $\left.\mathrm{CDCl}_{3}\right) \delta 15.1$ and $14.7,19.1$ and $19.3,25.3$ and 25.2, 25.7 and $27.5,36.0$ and $36.5,40.2$ and $39.7,42.9$ and $42.8,54.6$ and 52.9, 61.8 and 61.7, 67.1 and 67.0, 127.9 and 127.8, 128.0, 128.4 and 128.5, 137.4 and 137.3, 153.7 and 153.3, 155.6 and 156.0, 175.8 and 175.9; MS (EI): $m / z, 225$ (7\%), 218 (28\%), 175 (7\%), 174 (53\%), 138 (7\%), 92 (8\%), 91 (10\%0), 65 (5\%); HRMS (EI): found 360.1685; calc. for $\mathrm{C}_{19} \mathrm{H}_{24} \mathrm{~N}_{2} \mathrm{O}_{5}[\mathrm{M}]^{+} 360.1685$.

(2SR, l'SR) and (2RS, l'SR) Methyl-2-[ 2'- (2- oxo- 1,3oxazolan-3-yl)- 1'- methyl- 2'-oxoethyl]-1-azolanecarboxylate (29/30)

Reaction temperatures $\mathrm{T} 1=\mathrm{T} 2=-23{ }^{\circ} \mathrm{C}$. The product was purified by chromatography on silica gel (impregnated with $\mathrm{Et}_{3} \mathrm{~N}, 50 \%$ ethyl acetate-hexane) to afford a 10:1 mixture of 29 and $\mathbf{3 0}$ (0.13 g, 50\%; determined by GC analysis) as an oil. Found: C, 53.14; H, 6.52; N, 10.33.
Calc. for $\mathrm{C}_{12} \mathrm{H}_{18} \mathrm{~N}_{2} \mathrm{O}_{5} \mathrm{C}, 53.33 ; \mathrm{H}, 6.71 ; \mathrm{N}, 10.36 \%$. IR $v_{\max } / \mathrm{cm}^{-1} 1776,1699$; Data for 29: ${ }^{1} \mathrm{H}$ NMR $(300 \mathrm{MHz}$; $\left.60{ }^{\circ} \mathrm{C} ; \mathrm{CDCl}_{3}\right) \delta 1.12(\mathrm{~d}, J 7.0 \mathrm{~Hz}, 3 \mathrm{H}), 1.73-1.87(\mathrm{~m}, 1 \mathrm{H})$, 1.87-2.05 (m, 3H), 3.24-3.37 (m, 1H), 3.37-3.51 (m, $1 \mathrm{H})$, $3.63(\mathrm{~s}, 3 \mathrm{H}), 3.91-4.02(\mathrm{~m}, 2 \mathrm{H}), 4.02-4.10(\mathrm{~m}, 1 \mathrm{H}), 4.14$ (qt, $J 6.9 \mathrm{~Hz}, 1 \mathrm{H}), 4.22-4.43(\mathrm{~m}, 2 \mathrm{H}) ;{ }^{13} \mathrm{C} \mathrm{NMR}(75.5 \mathrm{MHz}$; $\left.60{ }^{\circ} \mathrm{C} ; \mathrm{CDCl}_{3}\right) \delta 13.0,23.4,28.7,39.9,43.1,46.9,52.0$, $60.2,61.8,153.4,156.0,175.5$.

(2SR, I'SR) and (2RS, I'SR) Methyl-2- [ 2'- (2- oxo- 1,3oxazolan- 3-yl)- 1'- methyl-2' -oxoethyl]- 1- piperidinecarboxylate (31/32)

Reaction temperatures $\mathrm{T} 1=\mathrm{T} 2=-23{ }^{\circ} \mathrm{C}$. The product was purified by chromatography on silica gel (impregnated with $\mathrm{Et}_{3} \mathrm{~N}, 50 \%$ ethyl acetate-hexane) to afford a 1.2:1 mixture of $\mathbf{3 1}$ and $\mathbf{3 2}(0.20 \mathrm{~g}, 70 \%$ determined by GC analysis) as a colorless solid. The isomers were separated by flash chromatography on silica gel (impregnated with $\mathrm{Et}_{3} \mathrm{~N}, 30 \%$ ethyl acetate-hexane). MS (EI): m/z 143 (9\%), $142(100 \%), 70(12 \%), 42(6 \%)$; HRMS (EI): found 284.1376; calc. for $\mathrm{C}_{13} \mathrm{H}_{20} \mathrm{~N}_{2} \mathrm{O}_{5}[\mathrm{M}]^{+}$284.1372. Data for 31: $\mathrm{mp}$ 104.1-104. $8^{\circ} \mathrm{C}$; IR $v_{\max } / \mathrm{cm}^{-1} 1774,1701 ;{ }^{1} \mathrm{H}$ NMR $\left(300 \mathrm{MHz} ; 50{ }^{\circ} \mathrm{C} ; \mathrm{CDCl}_{3}\right) \delta 1.16(\mathrm{~d}, J 6.3 \mathrm{~Hz}, 3 \mathrm{H}), 1.30-$ $1.50(\mathrm{~m}, 1 \mathrm{H}), 1.50-1.70(\mathrm{~m}, 4 \mathrm{H}), 1.70-1.90(\mathrm{~m}, 1 \mathrm{H}), 2.98$ (dt, $J 11.1$ and $3.0 \mathrm{~Hz}, 1 \mathrm{H}), 3.67(\mathrm{~s}, 3 \mathrm{H}), 3.90-4.07(\mathrm{~m}$, $3 \mathrm{H}), 4.28-4.42(\mathrm{~m}, 2 \mathrm{H}), 4.50-4.65(\mathrm{~m}, 2 \mathrm{H}) ;{ }^{13} \mathrm{C} \mathrm{NMR}(75.5$ $\left.\mathrm{MHz} ; 50{ }^{\circ} \mathrm{C} ; \mathrm{CDCl}_{3}\right) \delta 15.3,19.1,25.3,25.6,35.9,40.1$, 43.0, 52.5, 54.3, 61.9, 153.5, 156.1, 175.6. Data for 32: IR $v_{\max } / \mathrm{cm}^{-1} 1774,1741,1701 ;{ }^{1} \mathrm{H}$ NMR $\left(300 \mathrm{MHz} ; 50{ }^{\circ} \mathrm{C}\right.$; $\left.\mathrm{CDCl}_{3}\right) \delta 1.10(\mathrm{~d}, J 6.8 \mathrm{~Hz}, 3 \mathrm{H}), 1.30-1.50(\mathrm{~m}, 2 \mathrm{H}), 1.50-$ $1.70(\mathrm{~m}, 4 \mathrm{H}), 2.74(\mathrm{t}, J 12.6 \mathrm{~Hz}, 1 \mathrm{H}), 3.70(\mathrm{~s}, 3 \mathrm{H}), 4.03(\mathrm{t}$, $J 8.1 \mathrm{~Hz}, 2 \mathrm{H}), 4.05-4.15(\mathrm{~m}, 1 \mathrm{H}), 4.41(\mathrm{t}, J 8.1 \mathrm{~Hz}, 2 \mathrm{H})$, 4.35-4.50 (m, 1H), 4.60-4.72 (m, 1H); ${ }^{13} \mathrm{C}$ NMR $(75.5$ $\left.\mathrm{MHz} ; 50{ }^{\circ} \mathrm{C} ; \mathrm{CDCl}_{3}\right) \delta 14.7,19.4,25.2,27.5,36.3,39.6$, $42.8,52.4,52.7,61.8,153.1,156.5,175.7$.

(2S, 1'S) and (2R, 1'S) Benzyl 2- \{2'- [(4R)- 4- benzyl- 2oxo-1,3-oxazolan- 3-yl]- 1' methyl-2'- oxoethyl\}-1azolanecarboxylate (33/34)

Reaction temperatures $\mathrm{T} 1=0{ }^{\circ} \mathrm{C}, \mathrm{T} 2=-23{ }^{\circ} \mathrm{C}$. The product was purified by chromatography on silica gel (impregnated with $\mathrm{Et}_{3} \mathrm{~N}, 20 \%$ ethyl acetate-hexane) to afford a 5:1 mixture of $\mathbf{3 3}$ and $\mathbf{3 4}(0.25 \mathrm{~g}, 57 \%$; determined by GC and ${ }^{1} \mathrm{H}$ NMR analysis) as an oil. MS (EI): $\mathrm{m} / z 204$ (5\%), 160 (17\%), 149 (15\%), 124 (15\%), 92 (7\%), 91 (100\%), 65 (7\%); HRMS (EI): found 301.1553; calc. for $\mathrm{C}_{17} \mathrm{H}_{21} \mathrm{~N}_{2} \mathrm{O}_{3}[\mathrm{M}-\mathrm{Cbz}]^{+}$301.1552. Data for 33: IR $v_{\max } / \mathrm{cm}^{-1}$ 1785,$1709 ;{ }^{1} \mathrm{H}$ NMR $\left(300 \mathrm{MHz} ; 60{ }^{\circ} \mathrm{C} ; \mathrm{CDCl}_{3}\right) \delta 1.14(\mathrm{~d}$, $J 6.6 \mathrm{~Hz}, 3 \mathrm{H}), 1.76-1.90(\mathrm{~m}, 1 \mathrm{H}), 1.90-2.10(\mathrm{~m}, 3 \mathrm{H}), 2.43$ 
(br t, $J 13.3 \mathrm{~Hz}, 1 \mathrm{H}), 3.29-3.50(\mathrm{~m}, 2 \mathrm{H}), 3.50-3.70(\mathrm{~m}$, $1 \mathrm{H}), 4.02$ (dd, $J 3.5$ and $9.0 \mathrm{~Hz}, 1 \mathrm{H}), 4.11(\mathrm{dd}, J 3.0$ and $7.2 \mathrm{~Hz}, 1 \mathrm{H}), 4.20-4.35$ (m, 2H), 4.57-4.65 (m, 1H), 5.08 $(\mathrm{d}, J 12.6 \mathrm{~Hz}, 1 \mathrm{H}), 5.15(\mathrm{~d}, J 12.6 \mathrm{~Hz}, 1 \mathrm{H}), 7.10-7.40(\mathrm{~m}$, $10 \mathrm{H}) ;{ }^{13} \mathrm{C} \mathrm{NMR}\left(75.5 \mathrm{MHz} ; 50{ }^{\circ} \mathrm{C} ; \mathrm{CDCl}_{3}\right) \delta 13.1,23.7$ 28.4, 38.0, 40.5, 47.1, 55.5, 59.9, 66.1, 66.7, 127.1, 127.7, $128.3,128.8,128.9,129.3,136.0,137.2$, 153.1, 155.1, 175.1. Data for 34: ${ }^{1} \mathrm{H}$ NMR $\left(300 \mathrm{MHz} ; 50{ }^{\circ} \mathrm{C} ; \mathrm{CDCl}_{3}\right)$ $\delta 1.19(\mathrm{~d}, J 7.0 \mathrm{~Hz}, 3 \mathrm{H}), 1.76-1.90(\mathrm{~m}, 1 \mathrm{H}), 1.90-2.10(\mathrm{~m}$, $3 \mathrm{H} 3), 2.61$ (dd, $J 11.0$ and $10.2 \mathrm{~Hz}, 1 \mathrm{H}), 3.29-3.50(\mathrm{~m}$, $2 \mathrm{H}), 3.50-3.70(\mathrm{~m}, 1 \mathrm{H}), 4.02(\mathrm{dd}, J 3.5$ and $9.0 \mathrm{~Hz}, 1 \mathrm{H})$, $4.11(\mathrm{dd}, J 3.0$ and $7.2 \mathrm{~Hz}, 1 \mathrm{H}), 4.20-4.35(\mathrm{~m}, 1 \mathrm{H}), 4.35-$ $4.46(\mathrm{~m}, 1 \mathrm{H}), 4.60-4.70(\mathrm{~m}, 1 \mathrm{H}), 5.09$ (d, J $12.6 \mathrm{~Hz}, 1 \mathrm{H})$, $5.12(\mathrm{~d}, J 12.6 \mathrm{~Hz}, 1 \mathrm{H}), 7.10-7.40(\mathrm{~m}, 10 \mathrm{H}) ;{ }^{13} \mathrm{C}$ NMR $(75.5$ $\left.\mathrm{MHz} ; 50{ }^{\circ} \mathrm{C} ; \mathrm{CDCl}_{3}\right) \delta 13.8,23.7,29.9,38.2,40.5,46.9$, 55.6, 59.7, 66.2, 66.9, 127.2, 127.8, 128.3, 128.8, 128.9, $129.3,136.0,137.2,153.2,155.7,175.5$.

(2S, I'S) and (2R, 1'S) Benzyl 2- \{2'- [(4R)- 4- benzyl- 2oxo- 1,3-oxazolan- 3-yl]- 1'- methyl-2'-oxoethyl\}hexahydro-1- pyridinecarboxylate (35/36)

Reaction temperatures $\mathrm{T} 1=\mathrm{T} 2=0{ }^{\circ} \mathrm{C}$. The product was purified by chromatography on silica gel (impregnated with $\mathrm{Et}_{3} \mathrm{~N}, 20 \%$ ethyl acetate-hexane) to afford a 1.8:1 mixture of 35 and 36 ( $0.23 \mathrm{~g}, 50 \%$; determined HPLC and ${ }^{1} \mathrm{H}$ NMR analysis) as an oil. The isomers were separated by flash chromatography on silica gel (impregnated with $\mathrm{Et}_{3} \mathrm{~N}, 15 \%$ ethyl acetate-hexane). MS (EI): $\mathrm{m} / z 315(11 \%), 218$ (36\%), 175 (8\%), 174 (61\%), 138 (8\%), 92 (8\%), 91 (100\%), 55 (5\%); HRMS (EI): found 450.2152; calc. for $\mathrm{C}_{26} \mathrm{H}_{30} \mathrm{~N}_{2} \mathrm{O}_{5}$ $[\mathrm{M}]^{+}$450.2155. Data for 35: colorless solid; $\mathrm{mp}$ 123.2$123.9^{\circ} \mathrm{C} ;[\alpha]_{\mathrm{D}}{ }^{20}-163.48\left(c 1.3, \mathrm{CH}_{2} \mathrm{Cl}_{2}\right) ; \mathrm{IR} v_{\max } / \mathrm{cm}^{-1} 1776$, 1770; ${ }^{1} \mathrm{H}$ NMR $\left(300 \mathrm{MHz} ; 50{ }^{\circ} \mathrm{C} ; \mathrm{CDCl}_{3}\right) \delta 1.19(\mathrm{~d}, J 6.2$ $\mathrm{Hz}, 3 \mathrm{H}), 1.34-1.52$ (m, 1H), 1.54-1.70 (br d, J 5.5 Hz, 4H), 1.74-1.90 (br d, $J 6.2 \mathrm{~Hz}, 1 \mathrm{H}), 2.50$ (dd, $J 8.2$ and $11.2 \mathrm{~Hz}$, $1 \mathrm{H}), 3.08-3.20(\mathrm{~m}, 1 \mathrm{H}), 3.14(\mathrm{~d}, J 2.8$ and $13.4 \mathrm{~Hz}, 1 \mathrm{H})$, $4.02-4.22(\mathrm{~m}, 3 \mathrm{H}), 4.59-4.78(\mathrm{~m}, 3 \mathrm{H}), 5.05(\mathrm{~d}, J 12.8 \mathrm{~Hz}$, $1 \mathrm{H}), 5.11(\mathrm{~d}, J 12.5 \mathrm{~Hz}, 1 \mathrm{H}), 7.00-7.50(\mathrm{~m}, 10 \mathrm{H}) ;{ }^{13} \mathrm{C} \mathrm{NMR}$ $\left(75.5 \mathrm{MHz} ; 50{ }^{\circ} \mathrm{C} ; \mathrm{CDCl}_{3}\right) \delta 15.2,19.0,25.4,25.6,36.0$, $37.8,40.2$, 54.7, 55.3, 65.9, 67.1, 127.4, 127.9, 128.0, $128.5,129.0,129.6,135.7,137.3,153.8,155.6,175.9$; Data for 36: colorless oil; $[\alpha]_{\mathrm{D}}{ }^{20}-70.42\left(c 1.7, \mathrm{CH}_{2} \mathrm{Cl}_{2}\right)$; ${ }^{1} \mathrm{H} \mathrm{NMR}$ $\left(300 \mathrm{MHz} ; 50{ }^{\circ} \mathrm{C} ; \mathrm{CDCl}_{3}\right) \delta 1.09(\mathrm{~d}, J 6.2 \mathrm{~Hz}, 3 \mathrm{H}), 1.38-$ $1.80(\mathrm{~m}, 6 \mathrm{H}), 2.73(\mathrm{dd}, J 9.5$ and $13.2 \mathrm{~Hz}, 1 \mathrm{H}), 2.70-2.86$ (br m, 1H), 3.31 (dd, $J 3.3$ and $13.2 \mathrm{~Hz}, 1 \mathrm{H}), 4.04-4.28$ $(\mathrm{m}, 3 \mathrm{H}), 4.43-4.58(\mathrm{~m}, 1 \mathrm{H}), 4.65-4.86(\mathrm{~m}, 2 \mathrm{H}), 5.17$ (s, $2 \mathrm{H}), 7.10-7.60(\mathrm{~m}, 10 \mathrm{H}) ;{ }^{13} \mathrm{C} \mathrm{NMR}\left(75.5 \mathrm{MHz} ; 50{ }^{\circ} \mathrm{C}\right.$; $\left.\mathrm{CDCl}_{3}\right) \delta 14.8,19.2,25.2,27.6,36.3,38.1,39.6,53.1$, 55.4, 66.0, 67.1, 127.6, 128.0, 128.1, 128.6, 129.2, 129.5, $135.5,137.3,153.4,156.2,176.0$. $\left(2 S, l^{\prime} S\right)$ and (2R, l'S) Methyl 2-\{2'- [(4R)- 4- benzyl-2oxo-1,3-oxazolan- 3-yl]- 1'- methyl- 2'- oxoethyl\}- 1azolanecarboxylate (37/38)

Reaction temperatures $\mathrm{T} 1=0{ }^{\circ} \mathrm{C}, \mathrm{T} 2=-23{ }^{\circ} \mathrm{C}$. The product was purified by chromatography on silica gel (impregnated with $\mathrm{Et}_{3} \mathrm{~N}, 20 \%$ ethyl acetate-hexane) to afford a 6:1 mixture of $\mathbf{3 7}$ and $\mathbf{3 8}(0.18 \mathrm{~g}, 50 \%$; determined by HPLC and ${ }^{1} \mathrm{H}$ NMR analysis) as an oil. IR $v_{\max } / \mathrm{cm}^{-1}$ 1783, 1700; ${ }^{1} \mathrm{H}$ NMR (300 MHz; $\left.55{ }^{\circ} \mathrm{C} ; \mathrm{CDCl}_{3}\right) \delta 1.16$ and $1.21(\mathrm{~d}, J 6.5$ and $7.0 \mathrm{~Hz}$, respectively; $3 \mathrm{H}) 1.77-1.90$ $(\mathrm{m}, 1 \mathrm{H}), 1.90-2.10(\mathrm{~m}, 3 \mathrm{H}), 2.60$ and $2.72(\mathrm{dd}, J 10.4 /$ 13.3 and 9.2/12.3 Hz, respectively; $1 \mathrm{H}), 3.30-3.50(\mathrm{~m}, 2 \mathrm{H})$, $3.50-3.62(\mathrm{~m}, 1 \mathrm{H}), 3.68$ and $3.70(\mathrm{~s}, 3 \mathrm{H}), 4.08-4.22(\mathrm{~m}$, 2H), 4.22- 4.40 (m, 2H), 4.62-4.75 (m, 1H), 7.10-7.40 (m, $5 \mathrm{H}) ;{ }^{13} \mathrm{C} \mathrm{NMR}\left(75.5 \mathrm{MHz} ; 55{ }^{\circ} \mathrm{C} ; \mathrm{CDCl}_{3}\right) \delta 12.9,23.8$, 28.3, 38.1, 40.4, 47.2 and 47.0, 52.2 and 52.1, 55.6 and 55.5, 59.7 and 59.8, 66.1 and 66.2, 127.2, 129.0, 129.3, 135.9, 153.1, 155.9, 175.2; MS (EI): m/z 155 (9\%), 129 (7\%), 128 (100\%); HRMS (EI): found 184.0974; calc. for $\mathrm{C}_{9} \mathrm{H}_{14} \mathrm{NO}_{3}\left[\mathrm{M}-\mathrm{C}_{10} \mathrm{H}_{10} \mathrm{NO}_{2}\right]^{+} 184.0974$.

(2S, l'S) and (2R, l'S) Methyl 2-\{2'- [(4R)- 4- benzyl-2oxo-1,3-oxazolan- 3-yl]- 1'- methyl-2'- oxoethyl\}hexahydro-1-pyridinecarboxylate (39/40)

Reaction temperatures $\mathrm{T} 1=0{ }^{\circ} \mathrm{C}, \mathrm{T} 2=-23{ }^{\circ} \mathrm{C}$. The product was purified by chromatography on silica gel (impregnated with $\mathrm{Et}_{3} \mathrm{~N}, 20 \%$ ethyl acetate-hexane) to afford a 1.9:1 mixture of 39 and $\mathbf{4 0}(0.23 \mathrm{~g}, 61 \%$; determined by GC and ${ }^{1} \mathrm{H}$ NMR analysis) as an oil. IR $v_{\max } / \mathrm{cm}^{-1} 1777,1694 ;{ }^{1} \mathrm{H} \mathrm{NMR}\left(300 \mathrm{MHz} ; 50{ }^{\circ} \mathrm{C} ; \mathrm{CDCl}_{3}\right.$ ) $\delta 1.18$ and $1.11(\mathrm{~d}, J 6.6 \mathrm{~Hz}, 3 \mathrm{H}), 1.32-1.84(\mathrm{~m}, 6 \mathrm{H}), 2.60$ and 2.74 (dd, $J 9.5 / 13.6$ and 9.7/13.4 Hz, respectively; $1 \mathrm{H}$ ), 3.09 and $2.70-2.80$ (dt and $\mathrm{m}, J 2.6$ and $13.7 \mathrm{~Hz}, 1 \mathrm{H}$ ), 3.21 and 3.32 (dd, $J$ 3.3/13.6 and 3.3/ 13.4, respectively; $1 \mathrm{H}$ ), 3.64 and $3.72(\mathrm{~s}, 3 \mathrm{H}), 4.00-4.20(\mathrm{~m}, 3 \mathrm{H}), 4.60-4.78(\mathrm{~m}$, $2 \mathrm{H}), 4.60-4.78$ and $4.42-4.58(\mathrm{~m}, 1 \mathrm{H}), 7.14-7.36(\mathrm{~m}, 5 \mathrm{H})$; ${ }^{13} \mathrm{C} \mathrm{NMR}\left(75.5 \mathrm{MHz} ; 50{ }^{\circ} \mathrm{C} ; \mathrm{CDCl}_{3}\right) \delta 15.2$ and 14.6, 19.0 and 19.2, 25.3 and 25.1, 25.5 and 27.5, 36.0 and 36.3, 37.8 and 38.1, 40.1 and 39.5, 52.4 and 52.3, 54.7 and 53.0, 55.3 and 55.4, 66.0 and 66.1, 127.5 and 127.6, 129.1 and 129.2, $129.5,135.7$ and $135.5,153.8,156.3,176.1$; MS (EI): $\mathrm{m} / \mathrm{z} 143$ (7\%), 142 (100\%); HRMS (EI): found 315.1709; calc. for $\mathrm{C}_{18} \mathrm{H}_{23} \mathrm{~N}_{2} \mathrm{O}_{3}\left[\mathrm{M}-\mathrm{CO}_{2} \mathrm{Me}\right]^{+} 315.1709$.

$(2 R, 1 ' R)$ tert-Butyl 2- \{2'- [(4S)- 4- benzyl- 2- oxo- 1,3oxazolan-3-yl]- 1'- phenyl-2'- oxoethyl\}-1-azolanecarboxylate (52)

Reaction temperatures $\mathrm{T} 1=0{ }^{\circ} \mathrm{C}, \mathrm{T} 2=-23{ }^{\circ} \mathrm{C}$. The 
product was purified by flash chromatography on silica gel (20\% ethyl acetate-hexane) to yield the single isomer $\mathbf{5 2}$ $(0.33 \mathrm{~g}, 70 \%)$ as a colorless oil. $[\alpha]_{\mathrm{D}}{ }^{20}+165.8\left(c 3.2, \mathrm{CH}_{2} \mathrm{Cl}_{2}\right)$; IR $v_{\max } / \mathrm{cm}^{-1} 1778,1693 ;{ }^{1} \mathrm{H} \mathrm{NMR}\left(300 \mathrm{MHz} ; 60{ }^{\circ} \mathrm{C} ; \mathrm{CDCl}_{3}\right)$ $\delta 1.51(\mathrm{~s}, 9 \mathrm{H}), 1.40-1.70(\mathrm{~m}, 1 \mathrm{H}), 1.70-1.95(\mathrm{~m}, 3 \mathrm{H}), 2.74$ (dd, $J 9.9$ and $13.6 \mathrm{~Hz}, 1 \mathrm{H}), 3.03-3.22$ (br m, 1H), 3.35 (dt, $J 10.7$ and $7.8 \mathrm{~Hz}, 1 \mathrm{H}$ ), 3.50 (br d, $J 12.1 \mathrm{~Hz}, 1 \mathrm{H} 5$ ), $3.98(\mathrm{t}, J 8.8 \mathrm{~Hz}, 1 \mathrm{H}), 4.05(\mathrm{dd}, J 2.6$ and $8.8 \mathrm{~Hz}, 1 \mathrm{H})$, 4.52-4.72 (br m, 2H), 5.53 (br d, J $5.9 \mathrm{~Hz}, 1 \mathrm{H})$ 7.20-7.40 $(\mathrm{m}, 10 \mathrm{H}) ;{ }^{13} \mathrm{C} \mathrm{NMR}\left(75.5 \mathrm{MHz} ; 60{ }^{\circ} \mathrm{C} ; \mathrm{CDCl}_{3}\right) \delta 23.1$, 28.6, 28.9, 38.0, 46.6, 51.8, 55.9, 59.6, 65.8, 79.6, 127.2, $127.5,128.5,128.9,129.5,129.7,136.0,136.1,152.7$, 154.7, 172.8; MS (EI): m/z 295 (9\%), 170 (22\%), 118 (39\%), $114(72 \%), 113(7 \%), 91(25 \%), 90(7 \%), 70(75 \%)$, $69(9 \%), 68(13 \%), 57(100 \%)$; HRMS (EI): found 391.1655; calc. for $\mathrm{C}_{23} \mathrm{H}_{23} \mathrm{~N}_{2} \mathrm{O}_{4}\left[\mathrm{M}-\mathrm{OC}_{4} \mathrm{H}_{9}\right]^{+} 391.1658$.

$(2 R, 1 ' R)$ and (2S, l'R) Benzyl 2- \{2'- [(4S)- 4- benzyl-2oxo- 1,3-oxazolan-3-yl]- 1'- phenyl-2'- oxoethyl\} hexahydro-1-pyridinecarboxylate $(\mathbf{5 4 / 5 5})$

Reaction temperatures $\mathrm{T} 1=\mathrm{T} 2=0{ }^{\circ} \mathrm{C}$. The product was purified by flash chromatography on silica gel $(20 \%$ ethyl acetate-hexane) to afford a 12:1 mixture of $\mathbf{5 4}$ and 55 (0.31 g, 60\%; determined by ${ }^{1} \mathrm{H}$ NMR and HPLC analysis) as a colorless solid. Mp 56.2-56.9 ${ }^{\circ} \mathrm{C}$; IR $v_{\max } / \mathrm{cm}^{-1}$ 1774, 1697; MS (EI): m/z 174 (5\%), 118 (14\%), 97 (7\%), $95(9 \%), 91(70 \%), 85(9 \%), 83(30 \%), 81(27 \%), 73(5 \%)$, $71(10 \%), 69(63 \%), 68(9 \%), 67(12 \%), 65(5 \%), 58$ (100\%), 57 (29\%), 56 (7\%), 55 (32\%); HRMS (EI): found 377.1819; calc. for $\mathrm{C}_{23} \mathrm{H}_{25} \mathrm{~N}_{2} \mathrm{O}_{3}[\mathrm{M}-\mathrm{Cbz}]^{+}$377.1865. Data for 54: ${ }^{1} \mathrm{H} \mathrm{NMR}\left(300 \mathrm{MHz} ; 55^{\circ} \mathrm{C} ; \mathrm{CDCl}_{3}\right) \delta 1.24-1.82(\mathrm{~m}$, $6 \mathrm{H}), 2.67$ (dd, $J 9.3$ and $13.4 \mathrm{~Hz}, 1 \mathrm{H}), 3.14(\mathrm{dd}, J 2.9$ and $13.4 \mathrm{~Hz}, 1 \mathrm{H}), 3.12-3.32$ (m, 1H), 3.96-4.14 (m, 2H), 4.14$4.32(\mathrm{~m}, 1 \mathrm{H}), 4.52-4.66(\mathrm{~m}, 1 \mathrm{H}), 5.17$ (br s, 2H), 5.24$5.36(\mathrm{~m}, 1 \mathrm{H}), 6.03(\mathrm{~d}, J 11.4 \mathrm{~Hz}, 1 \mathrm{H}), 7.01-7.20(\mathrm{~d}, J$ $11.4 \mathrm{~Hz}, 2 \mathrm{H}), 7.20-7.45(\mathrm{~m}, 11 \mathrm{H}), 7.45-7.62$ (d, J 6.9 Hz, $2 \mathrm{H}$ ); ${ }^{13} \mathrm{C}$ NMR (75.5 MHz; $\left.55^{\circ} \mathrm{C} ; \mathrm{CDCl}_{3}\right) \delta 19.1,25.5$, 25.6, 37.9, 40.3, 47.3, 54.9, 55.5, 65.8, 67.3, 127.2, 127.8, $127.9,128.0,128.4,128.8,128.9,129.4,129.5,135.3$, $136.1,137.1,153.5,155.5,172.1$.

$\left(2 R, l^{\prime} R\right)$ and (2S, l'R) Methyl 2- \{2'- [(4S)- 4- benzyl-2oxo- 1,3-oxazolan-3-yl]- 1'- phenyl-2'- oxoethyl\} hexahydro-1-pyridinecarboxylate (56/57)

Reaction temperatures $\mathrm{T} 1=0{ }^{\circ} \mathrm{C}, \mathrm{T} 2=-23{ }^{\circ} \mathrm{C}$. The product was purified by flash chromatography on silica gel (20\% ethyl acetate-hexane) to afford a 8:1 mixture of 56 and 57 (0.32 g, 73\%; determined by GC and ${ }^{1} \mathrm{H}$ NMR analysis) as a colorless solid. The major isomer 56 was separated by recrystallization (ethyl acetate-hexane). Data for 56: $\mathrm{mp} 175.1-175.8^{\circ} \mathrm{C}$; $\left[\mathrm{a}_{\mathrm{D}}{ }^{20}+87.9\right.$ (c 2.0, $\mathrm{CH}_{2} \mathrm{Cl}_{2}$ ); IR $v_{\max } / \mathrm{cm}^{-1} 1783,1700 ;{ }^{1} \mathrm{H} \mathrm{NMR}\left(300 \mathrm{MHz} ; 50{ }^{\circ} \mathrm{C} ; \mathrm{CDCl}_{3}\right)$ $\delta 1.20-1.30(\mathrm{~m}, 1 \mathrm{H}), 1.35-1.60(\mathrm{~m}, 3 \mathrm{H}), 1.60-1.80(\mathrm{~m}, 2 \mathrm{H})$, $2.75\left(\mathrm{dd}, J\right.$ 9.2 and 13.6, $\left.\mathrm{CH}_{2}-3,1 \mathrm{H}\right), 3.18(\mathrm{dd}, J 2.9$ and $13.2 \mathrm{~Hz}, 1 \mathrm{H}), 3.12-3.27$ (m, 1H), 3.73 (s, 3H), 4.01-4.24 (m, 2H), 4.10-4.24 (m, 1H), 4.54-4.66 (m, 1H), 5.10-5.30 (m, 1H), $6.01(\mathrm{~d}, J 11.4 \mathrm{~Hz}, 1 \mathrm{H}), 7.16(\mathrm{~d}, J 6.6 \mathrm{~Hz}, 2 \mathrm{H})$, 7.20-7.42 (m, 6H), 7.55 (d, J 6.6 Hz, 2H). ${ }^{13} \mathrm{C} \mathrm{NMR}(75.5$ $\left.\mathrm{MHz} ; 50{ }^{\circ} \mathrm{C} ; \mathrm{CDCl}_{3}\right) \delta$ 19.0, 25.4, 25.5, 37.9, 40.1, 47.2, 52.7, 54.8, 55.5, 65.8, 127.4, 128.0, 129.0, 129.1, 129.5, 129.5, 135.4, 136.2, 153.7, 156.3, 172.4; MS (EI): $\mathrm{m} / z .143$ (5\%), 142 (100), 118 (5), 91 (5); HRMS (EI): found 436.1999; calc. for $\mathrm{C}_{25} \mathrm{H}_{28} \mathrm{~N}_{2} \mathrm{O}_{5}[\mathrm{M}]^{+} 436.1998$.

$\left(2 R, l^{\prime} R\right)$ tert-Butyl 2- \{2'- [(4S)- 4- benzyl-2-oxo- 1,3oxazolan- 3- yl]- 1'- chloropropyl-2'-oxoethyl\}- 1azolanecarboxylate (58)

Reaction temperatures $\mathrm{T} 1=\mathrm{T} 2=-23{ }^{\circ} \mathrm{C}$. The product was purified by flash chromatography on silica gel $(15 \%$ ethyl acetate-hexane) to yield the single isomer $\mathbf{5 8}(0.38 \mathrm{~g}$, $81 \%$ ) as a colorless oil. $[\alpha]_{\mathrm{D}}{ }^{20}+49.6\left(c\right.$ 3.6, $\left.\mathrm{CH}_{2} \mathrm{Cl}_{2}\right)$; IR $v_{\max } / \mathrm{cm}^{-1} 1780,1689 ;{ }^{1} \mathrm{H} \mathrm{NMR}\left(500 \mathrm{MHz} ; 50{ }^{\circ} \mathrm{C} ; \mathrm{CDCl}_{3}\right)$ $\delta 1.44(\mathrm{~s}, 9 \mathrm{H}), 1.50-2.20(\mathrm{~m}, 8 \mathrm{H}), 2.60(\mathrm{dd}, J 13.3$ and $10.4 \mathrm{~Hz}, 1 \mathrm{H}), 3.27$ (m, 1H), 3.40-3.65 (m, 2H), 3.50 (t, $J$ $6.40 \mathrm{~Hz}, 2 \mathrm{H}), 4.12$ (m, 2H), 4.20-4.35 (br s, 2H), 4.68 (m, 1H), $7.29(\mathrm{~m}, 5 \mathrm{H}) ;{ }^{13} \mathrm{C} \mathrm{NMR}\left(125 \mathrm{MHz} ; 50{ }^{\circ} \mathrm{C} ; \mathrm{CDCl}_{3}\right)$ $\delta$ 21.6, 23.6, 28.5, 28.7, 30.7, 38.2, 44.5, 45.7, 47.1, 55.6, 58.7, 66.1, 79.8, 127.2, 128.9, 129.3, 135.7, 153.1, 154.9, 174.0; MS (EI): m/z 295 (10\%), 204 (10\%), 188 (6\%), 186 (17\%), $182(7 \%), 181(6 \%), 178(6 \%), 170(17 \%), 134$ (6\%), $121(15 \%), 119(45 \%), 118(6 \%), 117(16 \%), 116$ (7\%), $115(10 \%), 114(74 \%), 96(7 \%), 92(12 \%), 91(50 \%)$, 86 (9\%), 70 (100\%), 68 (9\%), 65 (10\%), 57 (83\%), 55 (25), 53 (6\%); HRMS (EI): found 363.1475; calc. for $\mathrm{C}_{19} \mathrm{H}_{24} \mathrm{~N}_{2} \mathrm{O}_{3} \mathrm{Cl}[\mathrm{M}-\mathrm{Boc}]^{+} 363.1475$.

(2R, I'R) Benzyl 2- \{2'- [(4S)- 4- benzyl- 2- oxo- 1,3oxazolan-3-yl]- I'- chloropropyl-2'- oxoethyl\}- 1azolanecarboxylate (60)

Reaction temperatures $\mathrm{T} 1=\mathrm{T} 2=-23{ }^{\circ} \mathrm{C}$. The product was purified by flash chromatography on silica gel $(20 \%$ ethyl acetate-hexane) to yield $\mathbf{6 0}(0.36 \mathrm{~g}, 73 \%)$ as a colorless oil and a single isomer. $[\alpha]_{\mathrm{D}}^{20}+30,4\left(1,1, \mathrm{CH}_{2} \mathrm{Cl}_{2}\right)$; IR $v_{\max } / \mathrm{cm}^{-1} 1778,1693 ;{ }^{1} \mathrm{H} \mathrm{NMR}\left(300 \mathrm{MHz} ; 55^{\circ} \mathrm{C} ; \mathrm{CDCl}_{3}\right)$ $\delta$ 1.58-2.12 (m, 8H); 2.40 (1H, br t, J 10.8, CHHPh); 3.34$3.52(\mathrm{~m}, 2 \mathrm{H}) ; 3.45(\mathrm{t}, J 6.40 \mathrm{~Hz}, 2 \mathrm{H}) ; 3.52-3.69(\mathrm{~m}, 1 \mathrm{H})$; $4.04(\mathrm{dd}, \mathrm{J}=3.5$ and $8.9 \mathrm{~Hz}, 1 \mathrm{H}) ; 4.10(\mathrm{t}, J 8,1 \mathrm{~Hz}, 1 \mathrm{H})$ 4.24-4.40 (br m, 2H); 4.59-4.71 (m, J 3.4 and 14.3, 1H); 
5.08 (d, J 12,8 Hz, 1H); 5.13 (d, J $12.3 \mathrm{~Hz}, 1 \mathrm{H}) ; 7.10-7.20$ (m, 1H); 7.20-7.60 (m, 9H); ${ }^{13} \mathrm{C}$ NMR $\left(125 \mathrm{MHz} ; 50{ }^{\circ} \mathrm{C}\right.$; $\left.\mathrm{CDCl}_{3}\right) \delta 23.6 ; 25.8 ; 28.8 ; 30.7 ; 38.0 ; 44.5 ; 45.7 ; 47.2$; $55.6 ; 59.6 ; 66.1 ; 66.8 ; 127.2 ; 127.8 ; 128.4 ; 128.8 ; 128.9$; $129.3 ; 135.8 ; 137.1 ; 153.2 ; 155.2 ; 173.9 ; \mathrm{MS}(\mathrm{EI}): \mathrm{m} / \mathrm{z}$ 204 (25\%), 186 (11\%), 160 (39\%), 92 (6\%), 91 (100\%), 70 (5\%); HRMS (EI): found $363.1476 \mathrm{C}_{19} \mathrm{H}_{24} \mathrm{~N}_{2} \mathrm{O}_{3} \mathrm{Cl}$ [M$\mathrm{Cbz}]^{+} 363.1475$.

$\left(2 R, l^{\prime} R\right)$ and $\left(2 S, l^{\prime} R\right)$ Benzyl 2- \{2'- [(4S)- 4- benzyl- 2oxo-1,3-oxazolan-3-yl]- 1'- chloropropyl-2'- oxoethyl\}hexahydro- 1- pyridinecarboxylate (62/63)

Reaction temperatures $\mathrm{T} 1=\mathrm{T} 2=-23{ }^{\circ} \mathrm{C}$. The product was purified by flash chromatography on silica gel $(20 \%$ ethyl acetate-hexane) to afford a 4:1 mixture of $\mathbf{6 2}$ and $\mathbf{6 3}$ (0.31 g, 60\%; determined by ${ }^{1} \mathrm{H}$ NMR and HPLC analysis) as a colorless solid. mp 86.5-87.3 ${ }^{\circ} \mathrm{C}$; MS (EI): $m / z 219$ (7\%), 218 (63\%), 175 (11\%), 174 (74\%), 92 (8\%), 91 (100\%), 84 (5\%); HRMS (EI): found 377.1632; calc. for $\mathrm{C}_{20} \mathrm{H}_{26} \mathrm{~N}_{2} \mathrm{O}_{3} \mathrm{Cl}[\mathrm{M}-\mathrm{Cbz}]^{+}$377.1632. The isomers were separated by flash chromatography on silica gel (15\% ethyl acetate-hexane). Data for 62: $[\alpha]_{\mathrm{D}}{ }^{20}+89.7\left(1.1, \mathrm{CH}_{2} \mathrm{Cl}_{2}\right)$; IR $v_{\max } / \mathrm{cm}^{-1} 1772,1699 ;{ }^{1} \mathrm{H} \mathrm{NMR}\left(300 \mathrm{MHz} ; 55^{\circ} \mathrm{C} ; \mathrm{CDCl}_{3}\right)$ $\delta 1.28-1.94(\mathrm{~m}, 10 \mathrm{H}), 2.42(\mathrm{dd}, J 10.3$ and $13.3 \mathrm{~Hz}, 1 \mathrm{H})$, $3.11(\mathrm{t}, J 12.5 \mathrm{~Hz}, 1 \mathrm{H}), 3.18(\mathrm{dd}, J 3.1$ and $13.4 \mathrm{~Hz}, 1 \mathrm{H})$, 3.46-3.60 (m, 2H), 4.00-4.20 (m, 3H), 4.60-4.82 (m, 3H), $5.03(\mathrm{~d}, J 12.9 \mathrm{~Hz}, 1 \mathrm{H}), 5.08$ (d, J 5.1 Hz, 1H), 7.09 (d, $J$ $6.6 \mathrm{~Hz}, 2 \mathrm{H}), 7.10-7.40(\mathrm{~m}, 8 \mathrm{H}) ;{ }^{13} \mathrm{C} \mathrm{NMR}(75.5 \mathrm{MHz}$; $\left.55^{\circ} \mathrm{C} ; \mathrm{CDCl}_{3}\right) \delta 19.3,25.5,26.2,28.0,29.8,37.9,40.4$, 40.9 , 44.4, 54.5, 55.4, 66.0, 67.2, 127.2, 127.8, 128.4, $128.9,129.3,135.5,136.9,153.6,155.2,174.7$. Data for 63: $[\alpha]_{\mathrm{D}}^{20}+48.0\left(1.1, \mathrm{CH}_{2} \mathrm{Cl}_{2}\right)$; IR $v_{\max } / \mathrm{cm}^{-1} 1778,1699$; ${ }^{1} \mathrm{H}$ NMR (300 MHz; $55^{\circ} \mathrm{C} ; \mathrm{CDCl}_{3}$ ) $\delta 1.33-1.78$ (br m,10H), 2.65 (dd, $J 9.9$ and $13.2 \mathrm{~Hz}, 1 \mathrm{H}), 2.78$ (br t, $J 12.3 \mathrm{~Hz}$, $1 \mathrm{H}), 3.27-3.40(\mathrm{~m}, 3 \mathrm{H}), 4.00-4.20(\mathrm{~m}, 3 \mathrm{H}), 4.58-4.77(\mathrm{~m}$, $3 \mathrm{H}), 5.11$ (br d, $J 13.0 \mathrm{~Hz}, 1 \mathrm{H}), 5.17$ (br d, $J 13.0 \mathrm{~Hz}, 1 \mathrm{H})$, 7.10-7.40 (m, 10H); $\left.{ }^{13} \mathrm{C} \mathrm{NMR} \mathrm{(75.5} \mathrm{MHz;} 55{ }^{\circ} \mathrm{C} ; \mathrm{CDCl}_{3}\right)$ $\delta$ 19.4, 25.3, 27.5, 27.8, 29.6, 38.2, 39.9, 40.9, 44.4, 53.1, $55.6,66.1,67.3,127.5,128.0,128.5,129.0,129.3,135.2$, $137.1,153.3,155.7,174.8$.

(2S, 2'S)- 2- ( 1'- tert-butoxycarbonyl-azolan- 2'- yl) propanoic acid [(-)-41]

To a solution of $\mathbf{1 1}(0.23 \mathrm{~g}, 0.57 \mathrm{mmol})$ in THF $(3.2$ $\left.\mathrm{cm}^{3}\right)$ at $0{ }^{\circ} \mathrm{C}$ was added water $\left(0.81 \mathrm{~cm}^{3}\right), 30 \%$ aq. $\mathrm{H}_{2} \mathrm{O}_{2}$ soln. $\left(0.23 \mathrm{~cm}^{3}\right)$, and a soln. of $\mathrm{LiOH}$. $\mathrm{H}_{2} \mathrm{O}(0.040 \mathrm{~g}, 0.95$ $\mathrm{mmol})$ in water $\left(1.2 \mathrm{~cm}^{3}\right)$. The mixture was stirred $5 \mathrm{~h}$ at $0^{\circ} \mathrm{C}$ and a solution of $\mathrm{Na}_{2} \mathrm{SO}_{3}(0.29 \mathrm{~g}, 2.3 \mathrm{mmol})$ in water $\left(1.7 \mathrm{~cm}^{3}\right)$ was added. The mixture was let to stir $16 \mathrm{~h}$ at $\mathrm{rt}$, the solvent was evaporated under reduced pressure and the aqueous layer was extracted with $\mathrm{CH}_{2} \mathrm{Cl}_{2}\left(3 \times 5 \mathrm{~cm}^{3}\right)$. The combined $\mathrm{CH}_{2} \mathrm{Cl}_{2}$ extracts were dried over $\mathrm{MgSO}_{4}$, filtered and the solvent was removed under reduced pressure. Recrystallization ( $\mathrm{Et}_{2} \mathrm{O}:$ Hexane) yielded (R)-4-benzyl-2oxazolidinone $(0.092 \mathrm{~g}, 95 \%)$. The aqueous layer was acidified to $\mathrm{pH} 2.0$ with aq. $1 \mathrm{M} \mathrm{HCl}$ and extracted with ethyl acetate $\left(3 \times 5 \mathrm{~cm}^{3}\right)$. The combined ethyl acetate extracts were dried over $\mathrm{MgSO}_{4}$, filtered and the solvent was removed under reduced pressure. The residue was purified by chromatography on silica gel (10\% ethyl acetate:hexane) to afford the acid (-)-41 (0.13 g, 91\%) as a white solid: $\mathrm{mp}$ 104.6-105.7 ${ }^{\circ} \mathrm{C} ;[\alpha]_{\mathrm{D}}{ }^{20}-31.0\left(c 4.1, \mathrm{CH}_{2} \mathrm{Cl}_{2}\right)$; ${ }^{1} \mathrm{H}$ NMR $\left(300 \mathrm{MHz} ; 50{ }^{\circ} \mathrm{C} ; \mathrm{CDCl}_{3}\right) \delta 1.06(\mathrm{~d}, J 7.3 \mathrm{~Hz}$, $3 \mathrm{H}), 1.46(\mathrm{~s}, 9 \mathrm{H}), 1.70-1.90(\mathrm{~m}, 3 \mathrm{H}), 1.90-2.04(\mathrm{~m}, 1 \mathrm{H})$, 3.18-3.38 (m, 2H), 3.44-3.62 (m, 1H), 4.14-4.28 (m, 1H), 7.30-7.80 (m, 1H); ${ }^{13} \mathrm{C}$ NMR $\left(75.5 \mathrm{MHz} ; 50{ }^{\circ} \mathrm{C} ; \mathrm{CDCl}_{3}\right)$ $\delta$ 9.9, 23.7, 27.1, 28.3, 41.4, 47.2, 58.3, 79.8, 155.0, 179.6. Found: C, 59.28; $\mathrm{H}, 8.83 ; \mathrm{N}$, 5.61. Calc. for $\mathrm{C}_{12} \mathrm{H}_{21} \mathrm{NO}_{4} \mathrm{C}$, $59.24 ; \mathrm{H}, 8.70 ; \mathrm{N}, 5.76 \%$.

(2S, 2'S) 2- (1'- Benzyloxicarbonyl- hexahydro- 2'pyridinyl) propanoic acid (42)

The same procedure described above for the preparation of (-)-5 was employed for a 1.8:1 mixture of 27:28 (0.23 $\mathrm{g}, 0.57 \mathrm{mmol})$. Recrystallization $\left(\mathrm{Et}_{2} \mathrm{O}:\right.$ Hexane $)$ of the solid residue from the $\mathrm{CH}_{2} \mathrm{Cl}_{2}$ extract yielded (R)-4-benzyl-2oxazolidinone $(0.092 \mathrm{~g}, 95 \%)$. The residue isolated from the ethyl acetate extract was purified by chromatography on silica gel (15\% ethyl acetate/hexane) to afford a 1.8:1 mixture of 42 and the C-2'epimer $(0.13 \mathrm{~g}, 91 \%)$ as a colorless oil. IR $v_{\max } / \mathrm{cm}^{-1} 3162$ (br), 1735, 1700; ${ }^{1} \mathrm{H}$ NMR $\left(300 \mathrm{MHz} ; \mathrm{CDCl}_{3}\right) \delta 1.17$ and $1.10(\mathrm{~d}, J 6.8 \mathrm{~Hz}, 3 \mathrm{H}), 1.36-$ $1.80(\mathrm{~m}, 6 \mathrm{H}), 2.94-3.10$ and 2.68 ( $\mathrm{m}$ and $\mathrm{t}$, br, respectively, $J 12.5 \mathrm{~Hz} ; 2 \mathrm{H}), 4.05-4.20(\mathrm{~m}, 1 \mathrm{H}), 4.43$ and 4.50 (br d, $J$ 9.0 and $10.5 \mathrm{~Hz}$, respectively; $1 \mathrm{H}$ ), 5.09 and 5.13/5.17 (s and $\mathrm{d} / \mathrm{d}$, respectively, $J 12.7$ and $12.4 \mathrm{~Hz} ; 2 \mathrm{H}), 7.20-7.40$ (m, 5H), 8.00-8.10 (br m, 1H); ${ }^{13} \mathrm{C}$ NMR (75.5 MHz; $\left.\mathrm{CDCl}_{3}\right) \delta 14.4$ and 14.2, 18.6 and 18.9, 25.0 and 25.4, 27.3, 38.3 and $38.9,39.7$ and $39.4,53.8$ and 52.6, 67.2 and 67.1, 127.9, 127.9 and 128.0, 128.5, 136.9, 155.9 and 155.7, 180.8 and 179.8; MS (EI): $m / z 91$ (100\%); HRMS (EI): found 156.1023; calc. for $\mathrm{C}_{8} \mathrm{H}_{14} \mathrm{NO}_{2}[\mathrm{M}-\mathrm{Cbz}]^{+} 156.1025$.

(2SR, l'SR)- 2- [2'- (2- oxo- 1,3- oxazolan- 3- yl)-1'methyl-2'-oxoethyl]-1-pirrolidine (43)

Procedure A: To a stirred solution of $7(0.050 \mathrm{~g}, 0.16$ mmol) in $\mathrm{CH}_{2} \mathrm{Cl}_{2}\left(4.0 \mathrm{~cm}^{3}\right)$ at $0{ }^{\circ} \mathrm{C}$ was added $\mathrm{CF}_{3} \mathrm{CO}_{2} \mathrm{H}$ $\left(0.12 \mathrm{~cm}^{3}, 1.6 \mathrm{mmol}\right)$ dropwise. The reaction was followed 
by TLC analyses and quenched by the addition of saturated $\mathrm{NaHCO}_{3}$ solution. After extraction with $\mathrm{CH}_{2} \mathrm{Cl}_{2}$, the organic layer was dried over anhydrous $\mathrm{MgSO}_{4}$, filtered and concentrated in vacuo. The crude residue was purified by cromatography on silica gel (5\% methanol:chloroform) to provide $43(0.017 \mathrm{~g}, 50 \%)$ as a colorless solid.

Procedure B: To solution of 25 (0.045 g, $0.13 \mathrm{mmol})$ in $\mathrm{MeOH}\left(2.0 \mathrm{~cm}^{3}\right)$ was added $10 \% \mathrm{Pd}-\mathrm{C}(0.02 \mathrm{~g})$. The resulting suspension was stirred at ambient temperature for $12 \mathrm{hr}$ under hydrogen (1 atm). The reaction mixture was filtered through Celite, and the solvent was removed under reduced pressure. The residue was purified by chromatography on silica gel (5\% methanol/chloroform/a few drops of $\left.\mathrm{NH}_{4} \mathrm{OH}\right)$ to afford $43(0.021 \mathrm{~g}, 74 \%)$ as a white solid mp:75.0-75.8 ${ }^{\circ} \mathrm{C} ;{ }^{1} \mathrm{H} \mathrm{NMR}\left(300 \mathrm{MHz} ; \mathrm{CDCl}_{3}\right)$ $\delta 1.22(\mathrm{~d}, J 6.6 \mathrm{~Hz}, 3 \mathrm{H}), 1.45-1.55(\mathrm{~m}, 1 \mathrm{H}), 1.76-1.95(\mathrm{~m}$, $1 \mathrm{H}), 2.01-2.12(\mathrm{~m}, 1 \mathrm{H}), 2.24-2.39(\mathrm{~m}, 2 \mathrm{H}), 3.20-3.31(\mathrm{~m}$, 1H), 3.37 (ddd, $J 5.7,10.1$ and $12.5 \mathrm{~Hz}, 1 \mathrm{H}), 3.50$ (dt, $J$ 7.5 and $10.4 \mathrm{~Hz}, 1 \mathrm{H}), 3.58-3.87(\mathrm{~m}, 3 \mathrm{H}), 4.12$ (ddd, $J 3.7$, 5.1 and $13.8 \mathrm{~Hz}, 2 \mathrm{H}) ;{ }^{13} \mathrm{C} \mathrm{NMR}\left(75.5 \mathrm{MHz} ; \mathrm{CDCl}_{3}\right) \delta 11.4$, 22.7, 32.6, 42.0, 43.5, 45.9, 57.9, 61.8, 153.0, 172.9.

(2S, 2'R)- 2- (1'- tert-butoxycarbonyl-azolan-2'- yl) propanoic acid $(+)-44$

The same procedure described above for the preparation of (-)-41 was employed for (+)-12 (0.23 g, $0.57 \mathrm{mmol})$. Recrystallization (Et $\left.{ }_{2} \mathrm{O}: H e x a n e\right)$ yielded (R)-4-benzyl-2oxazolidinone $(0.092 \mathrm{~g}, 95 \%)$. The ethyl acetate extract was purified by chromatography on silica gel (10\% ethyl acetate/hexane) to afford the acid (+)-44 (0.13 g, 91\%) as a white solid: mp 100.5-102.0 ${ }^{\circ} \mathrm{C}$; IR $v_{\max } / \mathrm{cm}^{-1} 3483$ (br), 3174 (br), 1732, 1697; $[\alpha]_{\mathrm{D}}{ }^{20}+71.1$ (c 3.2 in $\mathrm{CH}_{2} \mathrm{Cl}_{2}$ ); ${ }^{1} \mathrm{H}$ NMR $\left(300 \mathrm{MHz} ; 50{ }^{\circ} \mathrm{C} ; \mathrm{CDCl}_{3}\right) \delta 1.16(\mathrm{~d}, J 7.3 \mathrm{~Hz}, 3 \mathrm{H})$, 1.46 (s, 9H), 1.70-2.06 (m, 4H), 2.94 (qt, $J 6.6 \mathrm{~Hz}, 1 \mathrm{H})$, 3.18-3.32 (m, 1H), 3.42-3.58 (m, 1H), 3.99-4.10 (m, 1H), 8.20-8.90 (m, 1H); ${ }^{13} \mathrm{C}$ NMR (75.5 MHz; $\left.50{ }^{\circ} \mathrm{C} ; \mathrm{CDCl}_{3}\right)$ $\delta$ 13.7, 23.2, 28.3, 28.7, 42.6, 46.7, 59.5, 79.9, 155.5, 179.9 . Found: C, 59.28; H, 8.83; N, 5.61. Calc. for $\mathrm{C}_{12} \mathrm{H}_{21} \mathrm{NO}_{4} \mathrm{C}$, 59.24; H, 8.70; N,5.76\%.

(2S, l'R) tert-Butyl-2- \{2'-[(4R)- 4- benzyl- 2- oxo-1,3oxazolan-3-yl]- 1'- methyl-2'-oxoethyl\}- 1-azolanecarboxylate [(-)-45]

To a solution of diisopropylamine $\left(0.073 \mathrm{~cm}^{3}, 0.52\right.$ $\mathrm{mmol})$ in THF $\left(1.0 \mathrm{~cm}^{3}\right)$ at $-78{ }^{\circ} \mathrm{C}$ was added a $1.96 \mathrm{M}$ solution of $\mathrm{n}$-BuLi $\left(0.27 \mathrm{~cm}^{3}, 0.52 \mathrm{mmol}\right)$ in hexane and the mixture was stirred $30 \mathrm{~min}$. at $-78^{\circ} \mathrm{C}$. A solution of $\mathbf{1 1}$ $(0.20 \mathrm{~g}, 0.50 \mathrm{mmol})$ in THF $\left(1.0 \mathrm{~cm}^{3}\right)$ was added dropwise, and the solution was stirred $1 \mathrm{hr}$ at $-78{ }^{\circ} \mathrm{C}$ when it was quenched with satd. aq. $\mathrm{NH}_{4} \mathrm{Cl}\left(2.0 \mathrm{~cm}^{3}\right)$. The layers were separated and the aqueous layer was extracted with $\mathrm{CH}_{2} \mathrm{Cl}_{2}$ $\left(2 \times 3 \mathrm{~cm}^{3}\right)$, and the combined organic layers were dried over $\mathrm{MgSO}_{4}$. After filtration, the solvent was removed under reduced pressure and the residue was purified by flash chromatography on silica gel to afford $11(0.081 \mathrm{~g}, 38 \%)$ eluted with $15 \%$ ethyl acetate/hexane, (-)-45 (0.081 g, 38\%) eluted with $12 \%$ ethyl acetate/hexane, and $\mathrm{N}$-acyl urea 46 $(0.050 \mathrm{~g}, 20 \%$; eluted with $30 \%$ ethyl acetate/hexane). Data for (-)-45: $[\alpha]_{\mathrm{D}}{ }^{20}-94.8$ (c 1.4 in $\mathrm{CH}_{2} \mathrm{Cl}_{2}$ ); ${ }^{1} \mathrm{H}$ NMR (300 $\left.\mathrm{MHz} ; 55^{\circ} \mathrm{C} ; \mathrm{CDCl}_{3}\right) \delta 1.23(\mathrm{~d}, J 7.0 \mathrm{~Hz}, 3 \mathrm{H}), 1.45(\mathrm{~s}, 9 \mathrm{H})$, 1.72-2.50 (m, 4H), 2.78 (dd, J 9.5 and $13.2 \mathrm{~Hz}, 1 \mathrm{H}), 3.16-$ 3.38 (m, 1H), 3.36-3.60 (br s, 1H), 3.38-3.64 (br m, 1H), 3.90-4.08 (br m, 1H), 4.13-4.20 (m, 2H), 4.22-4.40 (br s, 1H), 4.58-4.70 (m, 1H), 7.19-7.35 (m, 5H); ${ }^{13} \mathrm{C} \mathrm{NMR} \mathrm{(75.5}$ $\left.\mathrm{MHz} ; 5{ }^{\circ} \mathrm{C} ; \mathrm{CDCl}_{3}\right) \delta 13.9,23.6,28.4,29.5,38.0,41.8$, 47.0, 55.7, 59.1, 66.2, 79.4, 127.2, 128.9, 129.4, 135.6, 153.3, 155.2, 175.4. Data for 46: $[\alpha]_{\mathrm{D}}{ }^{20}+10.5$ (c 2.4 in $\mathrm{CH}_{2} \mathrm{Cl}_{2}$ ); IR $v_{\text {max }} / \mathrm{cm}^{-1} 3325$ (br), 1693; ${ }^{1} \mathrm{H}$ NMR (300 MHz; $55^{\circ} \mathrm{C} ; \mathrm{CDCl}_{3}$ ) $\delta 0.94$ (br d, J $6.9 \mathrm{~Hz}, 3 \mathrm{H}$ ), 1.22 (br d, J 6.4 $\mathrm{Hz}, 12 \mathrm{H}), 1.75$ (s, 9H), 1.56-1.88 (m, 4H), 2.84 (br d, J 6.9 Hz, 2H), 2.90-3.10 (br s, 1H), 3.14-3.28 (br m, 1H), 3.363.58 (br s, 1H), 3.78-4.00 (br m, 3H), 4.11 (br d, J $5.4 \mathrm{~Hz}$, 2H), 4.34-4.52 (m, 1H), 6.00-6.14 (m, 1H), 7.12-7.30 (m, $5 \mathrm{H}) ;{ }^{13} \mathrm{C}$ NMR $\left(75.5 \mathrm{MHz} ; 55{ }^{\circ} \mathrm{C} ; \mathrm{CDCl}_{3}\right) \delta 10.1,21.0$, 24.2, 26.4, 28.6, 38.0, 42.7, 46.2, 47.4, 50.3, 59.4, 65.4, $79.4,126.5,128.5,129.3,137.6,154.7,155.6,173.6$; MS (EI): $m / z 403$ (7\%), 402 (19\%), 365 (7\%), 334 (7\%), 257 (12\%), 190 (12\%), 189 (19\%), 170 (27\%), 137 (8\%), 128 (40\%), $124(26 \%), 120(7 \%), 117(16 \%), 114$ (42\%), 98 (17\%), 91 (17\%), 86 (38\%), 70 (100\%), 57 (61\%); HRMS (EI): found 503.3356; calc. for $\mathrm{C}_{28} \mathrm{H}_{45} \mathrm{~N}_{3} \mathrm{O}_{5}[\mathrm{M}]^{+} 503.3359$.

(2S, 2'R)- 2- (1'- tert-butoxycarbonyl-azolan- 2'- yl) propanoic acid [(-)-44]

The same procedure described above for the preparation of (-)-11 was employed for (-)-45 (0.23 g, $0.57 \mathrm{mmol})$. Recrystallization ( $\mathrm{Et}_{2} \mathrm{O}:$ Hexane) yielded (R)-4-benzyl-2oxazolidinone $(0.092 \mathrm{~g}, 95 \%)$. The residue isolated from the ethyl acetate extract was purified by chromatography on silica gel (10\% ethyl acetate/hexane) to afford (-)-44 $(0.13 \mathrm{~g}, 91 \%)$ as a white solid, in yield. $[\alpha]_{\mathrm{D}}{ }^{20}-75.7(c 2.4$ in $\mathrm{CH}_{2} \mathrm{Cl}_{2}$ ).

(2S, 2'S)- 2- (1'- benzyloxycarbonyl- hexahydro- pyridin2'-yl)- 2-methylethanol (47)

To a solution of $35(0.21 \mathrm{~g}, 0.46 \mathrm{mmol})$ in THF (3.42 $\mathrm{cm}^{3}$ ) at $0{ }^{\circ} \mathrm{C}$ was added dropwise a solution of $\mathrm{NaBH}_{4}$ 
$(0.70 \mathrm{~g}, 1.8 \mathrm{mmol})$ in $\mathrm{H}_{2} \mathrm{O}\left(0.43 \mathrm{~cm}^{3}\right)$. The mixture was stirred at room temperature for $16 \mathrm{hr}$, and quenched with a $2.0 \mathrm{~N}$ aqueous solution of $\mathrm{HCl}\left(1.24 \mathrm{~cm}^{3}\right)$. The mixture was extracted with $\mathrm{CH}_{2} \mathrm{Cl}_{2}$, and the organic layer dried with $\mathrm{MgSO}_{4}$. After filtration, the solvent was removed under reduced pressure and the residue was purified by chromatography on silica gel to afford $47(0.089 \mathrm{~g}, 70 \%$; $20 \%$ ethyl acetate/hexane) as a colorless oil and (R)-4benzyl-2-oxazolidinone $(0.067 \mathrm{~g}, 82 \%$; $50 \%$ ethyl acetate/ hexane). $[\alpha]_{\mathrm{D}}{ }^{20}-31.1$ ( $c 0.8$ in $\mathrm{CH}_{2} \mathrm{Cl}_{2}$ ); IR $v_{\text {max }} / \mathrm{cm}^{-1} 3460$ (br), 1678; ${ }^{1} \mathrm{H} \mathrm{NMR}\left(300 \mathrm{MHz} ; 50{ }^{\circ} \mathrm{C} ; \mathrm{CDCl}_{3}\right) \delta 1.02(\mathrm{~d}, J$ $6.9 \mathrm{~Hz}, 3 \mathrm{H}), 1.40-1.70$ (m, 6H), 1.78-1.90 (br m, 1H), 1.942.10 (br s, 1H), 2.77 (dt, $J 2.7$ and $11.8 \mathrm{~Hz}, 1 \mathrm{H}), 3.30-3.48$ (m, 2H), 4.08 (br d, $J 11.8 \mathrm{~Hz}, 2 \mathrm{H}), 5.13$ (d, J $12.4 \mathrm{~Hz}$, $1 \mathrm{H}), 5.17$ (d, $J 12.4 \mathrm{~Hz}, 1 \mathrm{H}), 7.20-7.41(\mathrm{~m}, 5 \mathrm{H}) ;{ }^{13} \mathrm{C}$ NMR $\left(75.5 \mathrm{MHz} ; \mathrm{CDCl}_{3}\right) \delta 14.7,18.7,25.3,25.7,32.5,39.8$, $52.1,64.1,67.4,127.9,128.2,128.6,136.5,156.9, \mathrm{MS}$ (CI): $m / z 280(6 \%), 279$ (42\%), 278 (100\%), $276(9 \%)$, 260 (15\%), 235 (26\%), 234 (78\%), 219 (7\%), 218 (44\%), 174 (17\%), 171 (6\%), 170 (49\%), 144 (12\%), $142(6 \%)$, $92(6 \%), 91(43 \%), 84(12 \%)$.

$(2 S, 2$ 'R)- 2- (1'- benzyloxycarbonyl- hexahydro- pyridin2'-yl)- 2-methylethanol (48)

The same procedure described above for $\mathbf{4 7}$ was employed starting with $36(0.21 \mathrm{~g}, 0.46 \mathrm{mmol})$. The residue was purified by chromatography on silica gel to afford 48 (0.09 g, $0.32 \mathrm{mmol}, 70 \% ; 30 \%$ ethyl acetate/hexane) as a colorless oil and (R)-4-benzyl-2-oxazolidinone $(0.067 \mathrm{~g}$, $82 \% ; 50 \%$ ethyl acetate/hexane). $[\alpha]_{\mathrm{D}}^{20}+15.0$ (c 1.7 in $\mathrm{CH}_{2} \mathrm{Cl}_{2}$ ); IR $v_{\max } / \mathrm{cm}^{-1} 3460$ (br), 1678; ${ }^{1} \mathrm{H} \mathrm{NMR}(300 \mathrm{MHz}$; $\left.50{ }^{\circ} \mathrm{C} ; \mathrm{CDCl}_{3}\right) \delta 0.90(\mathrm{~d}, J 6.9 \mathrm{~Hz}, 3 \mathrm{H}), 1.40-1.70(\mathrm{~m}, 5 \mathrm{H})$, 1.70-1.90 (br m, 2H), 2.04-2.18 (m, 1H), 2.78 (dt, J 2.9 and $14.0 \mathrm{~Hz}, 1 \mathrm{H}), 3.49$ (dd, $J 5.8$ and $11.0 \mathrm{~Hz}, 1 \mathrm{H}), 3.61$ (dd, $J 4.8$ and 10.9 Hz, 1H), 4.04-4.20 (br m, 2H), 5.13 (s, 2H), 7.20-7.41 (m, 5H); ${ }^{13} \mathrm{C} \mathrm{NMR}\left(75.5 \mathrm{MHz} ; \mathrm{CDCl}_{3}\right)$ $\delta 13.3,19.1,25.1,26.4,35.0,39.8,52.5,65.6,67.0,127.8$, $127.9,128.5,137.0,156.2$.

Benzyl (2S)- 2-isopropylhexahydro- 1-pyridinecarboxylate [(-)-49]

To a solution of $47(0.053 \mathrm{~g}, 0.19 \mathrm{mmol})$ in $\mathrm{CH}_{2} \mathrm{Cl}_{2}$ $\left(0.6 \mathrm{~cm}^{3}\right)$ at $0{ }^{\circ} \mathrm{C}$ was added $\mathrm{Et}_{3} \mathrm{~N}\left(0.029 \mathrm{~cm}^{3}, 0.21 \mathrm{mmol}\right)$, catalytic amount of DMAP, and $\mathrm{TsCl}(0.040 \mathrm{~g}, 0.21 \mathrm{mmol})$. The mixture was stirred $1 \mathrm{~h}$ at $0{ }^{\circ} \mathrm{C}$, the solvent removed under reduced pressure and the residue was purified by chromatography on silica gel (10\% ethyl acetate/hexane) to afford the tosylate $(0.060 \mathrm{~g}, 0.14 \mathrm{mmol})$ in $70 \%$ yield, which was dissolved in DME $\left(1.20 \mathrm{~cm}^{3}\right)$, and $\mathrm{NaI}(0.046$ $\mathrm{g}, 0.31 \mathrm{mmol}$ ) and catalytic amount of AIBN were added. The mixture was refluxed and then was added $\mathrm{nBu}_{3} \mathrm{SnH}$ $\left(0.052 \mathrm{~cm}^{3}, 0.18 \mathrm{mmol}\right)$. After $1 \mathrm{~h}$, the solvent was removed under reduced pressure, and the residue was purified by chromatography on silica gel (5\% ethyl acetate/hexane) to afford (-)-47 (0.022 $\mathrm{g}, 60 \%)$ as a colorless oil. $[\alpha]_{\mathrm{D}}{ }^{20}-3.2$ (c $0.34, \mathrm{CH}_{2} \mathrm{Cl}_{2}$ ); IR $v_{\max } / \mathrm{cm}^{-1} 1697 ;{ }^{1} \mathrm{H}$ NMR $(300 \mathrm{MHz}$; $\left.55^{\circ} \mathrm{C} ; \mathrm{CDCl}_{3}\right) \delta 0.83(\mathrm{~d}, J 7.0 \mathrm{~Hz}, 3 \mathrm{H}), 0.91(\mathrm{~d}, J 6.6 \mathrm{~Hz}$, $3 \mathrm{H}), 1.36-1.64$ (m, 5H), 1.74-1.83 (br m, 1H), 2.02-2.18 $(\mathrm{m}, 1 \mathrm{H}), 2.78$ (dt, $J 2.8$ and $12.5 \mathrm{~Hz}, 1 \mathrm{H}), 3.84$ (br d, $J 11.0$ $\mathrm{Hz}, 1 \mathrm{H}), 4.08$ (br d, J 12.5 Hz, 1H), 5.13 (s, 2H), 7.207.40 (m, 5H); ${ }^{13} \mathrm{C} \mathrm{NMR}\left(75.5 \mathrm{MHz} ; 55{ }^{\circ} \mathrm{C} ; \mathrm{CDCl}_{3}\right) \delta 19.2$, 19.3, 20.0, 25.6, 26.2, 26.3, 39.7, 57.6, 66.9, 127.8, 128.4, 137.5, 155.9; MS (EI): $m / z 219(5 \%), 218(35 \%), 175(8 \%)$, $174(66 \%), 92(8 \%), 91(100 \%)$; HRMS (EI): found 261.1737; calc. for $\mathrm{C}_{16} \mathrm{H}_{23} \mathrm{NO}_{2}[\mathrm{M}]^{+} 261.1729$.

Benzyl (2R)- 2- isopropylhexahydro- 1-pyridinecarboxylate $[(+)-47]$

The same procedure described above for (-)-47 was employed starting with (+)-48. [a] ${ }_{\mathrm{D}}^{20}+3.0\left(c 0.4, \mathrm{CH}_{2} \mathrm{Cl}_{2}\right)$.

(2'S)- 2- (1'- tert- butoxycarbonyl- hexahydro- pyridin$\left.2^{\prime}-y l\right)$ - ethanoic acid (50)

The same procedure described above for the preparation of (-)-44 was employed for 19 (0.23 g, $0.57 \mathrm{mmol})$. Recrystallization ( $\mathrm{Et}_{2} \mathrm{O}:$ Hexane) yielded (R)-4-benzyl-2oxazolidinone $(0.091 \mathrm{~g}, 95 \%)$ in yield. The residue from the ethyl acetate extract was purified by chromatography on silica gel (10\% ethyl acetate/hexane) to afford $\mathbf{5 0}(0.12$ $\mathrm{g}, 85 \%$ ) as a white solid. IR $v_{\max } / \mathrm{cm}^{-1} 3467$ (br), 3145, 1732, 1693; ${ }^{1} \mathrm{H}$ NMR (500 MHz; $\left.\mathrm{CDCl}_{3}\right) \delta 1.30-1.50$ (m, 2H), $1.44(\mathrm{~s}, 9 \mathrm{H}), 1.55-1.80(\mathrm{~m}, 4 \mathrm{H}), 2.55$ (dd, $J 14.5$ and 7.7 $\mathrm{Hz}, 1 \mathrm{H}$ ), 2.62 (dd, $J 7.4$ and $14.5 \mathrm{~Hz}, 1 \mathrm{H}$ ), 2.77 (br t, $J$ $11.8 \mathrm{~Hz}, 1 \mathrm{H}$ ), 3.99 (br d, J 11.8 Hz, 1H), 4.60-4.78 (br m, $1 \mathrm{H}), 5.5-6.5$ (br m, 1H); ${ }^{13} \mathrm{C} \mathrm{NMR}\left(75.5 \mathrm{MHz} ; \mathrm{CDCl}_{3}\right.$ ) $\delta$ 18.8, 25.1, 28.2, 28.3, 35.2, 39.2, 47.7, 80.0, 155.1, 176.5; MS (EI): $m / z 187$ (9\%), 184 (6\%), 170 (8\%), 142 (17\%), 129 (5\%), 128 (75\%), 84 (100\%), 57 (66\%); HRMS (EI): found 243.1471; calc. for $\mathrm{C}_{12} \mathrm{H}_{21} \mathrm{NO}_{4}[\mathrm{M}]^{+} 243.1470$.

Methyl-2- [(2'S)- 1'- (tert-butoxycarbonyl)- hexahydropyridin- 2'- yl] etanoate (51)

A solution of $\mathbf{5 0}(0.12 \mathrm{~g}, 0.48 \mathrm{mmol})$ in $\mathrm{Et}_{2} \mathrm{O}\left(2.5 \mathrm{~cm}^{3}\right)$ was treated with excess of an ethereal soln. of diazomethane. The solvent was evaporated and the crude mixture purified by chromatography on silica gel (5\% ethyl acetate-hexane) to afforded $51(0.12 \mathrm{~g}, 95 \%)$ as an colorless oil. $[\alpha]_{\mathrm{D}}{ }^{20}-12.5$ 
(c 4.8 in $\left.\mathrm{CHCl}_{3}\right)\left[\mathrm{Lit}^{19}:[\mathrm{a}]_{\mathrm{D}}{ }^{20}-8.30\left(\right.\right.$ c 5.5 in $\left.\left.\mathrm{CHCl}_{3}\right)\right]$; IR $v_{\text {max }} / \mathrm{cm}^{-1} 1739,1693 ;{ }^{1} \mathrm{H}$ NMR (300 MHz; $\left.\mathrm{CDCl}_{3}\right) \delta 1.45$ (s, 9H), 1.34-1.54 (m, 2H), 1.54-1.70 (m, 4H), 2.52 (dd, $J$ 7.7 and $14.0 \mathrm{~Hz}, 1 \mathrm{H}), 2.60(\mathrm{dd}, J 7.4$ and $14.0 \mathrm{~Hz}, 1 \mathrm{H})$, 2.78 (br t, $J 12.5 \mathrm{~Hz}, 1 \mathrm{H}$ ), 3.66 (s, 3H), 3.90-4.06 (br m, $1 \mathrm{H})$, 4.66-4.74 (br m, 1H); ${ }^{13} \mathrm{C}$ NMR $\left(75.5 \mathrm{MHz} ; 55^{\circ} \mathrm{C}\right.$; $\left.\mathrm{CDCl}_{3}\right) \delta 18.8,25.2,28.2,28.3,35.0,39.1,47.8,51.6,79.5$, 154.7, 171.9; MS (EI): $m / z 184(5 \%), 170(5 \%), 156(30 \%)$, 142 (26\%), 128 (48\%), 84 (100\%), 57 (81\%); HRMS (EI): found 201.1003; calc. for $\mathrm{C}_{9} \mathrm{H}_{15} \mathrm{NO}_{4}\left[\mathrm{M}_{-} \mathrm{C}_{4} \mathrm{H}_{8}\right]^{+} 201.1001$.

Methyl- $\left(2 R, 2^{\prime} R\right)-2-\left(l^{\prime}-\right.$ benzyloxycarbonyl- hexahydropyridin-2'-yl)-2- phenylethanoic (68)

The same procedure described above for the preparation of (-)-11 was employed for $\mathbf{5 6}$, as a 12:1 mixture with $\mathbf{5 7}$ $(0.29 \mathrm{~g}, 0.57 \mathrm{mmol})$. Recrystallization ( $\mathrm{Et}_{2} \mathrm{O}:$ Hexane) yielded (S)-4-benzyl-2-oxazolidinone (0.091 g, 90\%). The residue isolated from the ethyl acetate extract was purified by chromatography on silica gel (10\% ethyl acetate/hexane) to afford the corresponding carboxylic acid $67(0.17 \mathrm{~g}$, $0.48 \mathrm{mmol})$. A solution of the above carboxylic acid $(0.17$ $\mathrm{g}, 0.48 \mathrm{mmol})$ in $\mathrm{Et}_{2} \mathrm{O}\left(2.5 \mathrm{~cm}^{3}\right)$ was treated with excess diazomethane in ether. The solution was evaporated and the crude mixture purified by chromatography on silica gel (15\% ethyl acetate-hexane) to afford $\mathbf{6 8}(0.17 \mathrm{~g}, 81 \%)$ as a $12: 1$ mixture with its $2 \mathrm{~S}$ epimer (determined by CGMS). Data for major 68: $[\alpha]_{\mathrm{D}}-34.0\left(c 1.5\right.$ in $\left.\mathrm{CH}_{2} \mathrm{Cl}_{2}\right)$; IR $v_{\max } / \mathrm{cm}^{-1} 1738,1699 ;{ }^{1} \mathrm{H} \mathrm{NMR}\left(300 \mathrm{MHz} ; 55^{\circ} \mathrm{C} ; \mathrm{CDCl}_{3}\right)$ $\delta 1.20-1.80(\mathrm{~m}, 6 \mathrm{H}), 3.09$ (br t, $J 12.5 \mathrm{~Hz}, 1 \mathrm{H}), 3.44$ (s, $3 \mathrm{H}), 4.08-4.18(\mathrm{~m}, 1 \mathrm{H}), 4.16(\mathrm{~d}, J 11.7 \mathrm{~Hz}, 1 \mathrm{H}), 4.90-5.04$ (m, 1H), $5.13(\mathrm{~d}, J 12.5 \mathrm{~Hz}, 1 \mathrm{H}), 5.19(\mathrm{~d}, J 12.5 \mathrm{~Hz}, 1 \mathrm{H})$, 7.20-7.60 (m, 10H); ${ }^{13} \mathrm{C}$ NMR $\left(75.5 \mathrm{MHz} ; 55^{\circ} \mathrm{C} ; \mathrm{CDCl}_{3}\right)$ $\delta 18.8,25.3,25.4,39.7,51.5,51.7,54.2,67.2,127.7,127.8$, 127.9, 128.2, 128.7, 128.9, 136.2, 137.2, 155.4, 172.1; MS (EI): 218 (27\%), 175 (7\%), 174 (47\%), $121(6 \%), 92(8 \%)$, 91 (100\%), 65 (6\%); HRMS (EI): found 368.1864; calc. for $\mathrm{C}_{22} \mathrm{H}_{25} \mathrm{NO}_{4}[\mathrm{MH}]^{+} 368.1862$.

$\left(2 R, 2^{\prime} R\right)-2-\left(I^{\prime}-\right.$ Methoxycarbonyl- hexahydro- pyridin2'-yl)-2-phenyletanoic acid (69)

The same procedure described above for the preparation of (-)-11 was employed for $\mathbf{5 8}(0.25 \mathrm{~g}, 0.57 \mathrm{mmol})$. Recrystallization ( $\mathrm{Et}_{2} \mathrm{O}$ :Hexane) yielded (S)-4-benzyl-2oxazolidinone $(0.091 \mathrm{~g}, 90 \%)$. The residue isolated from the ethyl acetate extract was purified by recrystallization (ethyl acetate:hexane) to yield $\mathbf{6 9}(0.14 \mathrm{~g}, 90 \%)$ as a white solid. $[\alpha]_{\mathrm{D}}{ }^{20}-53.2\left(c 1.4\right.$ in $\left.\mathrm{CH}_{2} \mathrm{Cl}_{2}\right)$; mp 154.6-155.0 ${ }^{\circ} \mathrm{C}$; IR $v_{\max } / \mathrm{cm}^{-1} 3162$ (br), 3019, 1699; ${ }^{1} \mathrm{H}$ NMR (300 MHz; $\left.55^{\circ} \mathrm{C} ; \mathrm{CDCl}_{3}\right) \delta 1.27-1.70(\mathrm{~m}, 6 \mathrm{H}), 3.08($ br t, $J 13.2 \mathrm{~Hz}$,
1H), $3.66(\mathrm{~s}, 3 \mathrm{H}), 4.02-4.18(\mathrm{~m}, 1 \mathrm{H}), 4.14(\mathrm{~d}, J 11.4 \mathrm{~Hz}$, 1H), 4.82-5.04 (br m, 1H), 7.20-7.38 (m, 3H), 7.38-7.46 (br d, J 7.7 Hz, 2H), 8.22-8.60 (br s, 1H); ${ }^{13} \mathrm{C}$ NMR (75.5 $\left.\mathrm{MHz} ; 55^{\circ} \mathrm{C} ; \mathrm{CDCl}_{3}\right) \delta 18.8,25.2,25.4,39.7,51.2,52.7$, 54.0, 127.8, 128.8, 128.9, 135.9, 156.5, 175.7. Found: C, 64.84; H, 7.02; N, 4.92. Calc. for $\mathrm{C}_{15} \mathrm{H}_{19} \mathrm{NO}_{4} \mathrm{C}, 64.97 ; \mathrm{H}$, $6.91 ; \mathrm{N}, 5.05 \%$.

\section{$\left(2 R, 2^{\prime} R\right)$-Methylphenidate hydrochloride (66)}

From 68: To a solution of $\mathbf{6 8}(0.077 \mathrm{~g}, 0.21 \mathrm{mmol})$ in $\mathrm{MeOH}\left(2.6 \mathrm{~cm}^{3}\right)$ was added $10 \%$ Pd-C $(0.03 \mathrm{~g})$. The resulting suspension was stirred $12 \mathrm{~h}$ at ambient temperature under hydrogen $(1 \mathrm{~atm})$. The reaction mixture was filtered through Celite, and the solvent was removed under reduced pressure. The residue was stirred overnight with ethanolic $2 \mathrm{~N} \mathrm{HCl}\left(2.0 \mathrm{~cm}^{3}\right)$ at rt. Evaporation under

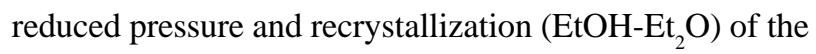
crude solid afforded $66(0.043 \mathrm{~g}, 76 \%)$ as a white solid as a single isomer by ${ }^{1} \mathrm{H}$ and ${ }^{13} \mathrm{C}$ NMR.

From 69: A mixture of $\mathrm{I}_{2}(0.058 \mathrm{~g}, 0.23 \mathrm{mmol})$ and hexamethyldisilane $(0.067 \mathrm{~g}, 0.46 \mathrm{mmol})$ was heated at $120^{\circ} \mathrm{C}$ under argon with stirring until a colorless solution resulted ( $2 \mathrm{~min}$ ). The solution was cooled to $25^{\circ} \mathrm{C}$ and a solution of $69(0.050 \mathrm{~g}, 0.18 \mathrm{mmol})$ in $\mathrm{CH}_{2} \mathrm{Cl}_{2}\left(0.5 \mathrm{~cm}^{3}\right)$ was added. The mixture was stirred for $5 \mathrm{~h}$ at $25{ }^{\circ} \mathrm{C}$, quenched with $\mathrm{MeOH}\left(1.0 \mathrm{~cm}^{3}\right)$ and the red color was discharged with saturated aqueous sodium bisulphite. The solvent was removed under reduced pressure and the residue was taken up in ether $\left(2.0 \mathrm{~cm}^{3}\right)$ and treated with excess of an ethereal soln. of diazomethane. The solution was evaporated to a light yellow oil which was stirred overnight with ethanolic $2 \mathrm{~N} \mathrm{HCl}\left(2.0 \mathrm{~cm}^{3}\right)$ at $\mathrm{rt}$. Evaporation under reduced pressure and recrystallization $\left(\mathrm{EtOH}_{-}-\mathrm{Et}_{2} \mathrm{O}\right)$ of the crude solid afforded $\mathbf{6 6}(0.031 \mathrm{~g}, 63 \%)$ as a white solid: $\mathrm{mp} 213.6-213.8{ }^{\circ} \mathrm{C}$ (lit ${ }^{155}: 221-223{ }^{\circ} \mathrm{C}$ ); $[\alpha]_{\mathrm{D}}+86.2(c 1.0, \mathrm{MeOH})\left(\mathrm{lit}^{22}:[\alpha]_{\mathrm{D}}+88(c 1.0, \mathrm{MeOH})\right)$; IR $v_{\max } / \mathrm{cm}^{-1} 1739 ;{ }^{1} \mathrm{H}$ NMR (300 MHz, $\left.\mathrm{CD}_{3} \mathrm{OD}\right) \delta 1.20-$ $1.45(\mathrm{~m}, 3 \mathrm{H}), 1.45-1.90(\mathrm{~m}, 3 \mathrm{H}), 3.02(\mathrm{dt}, J 3.3$ and 12.8 $\mathrm{Hz}, 1 \mathrm{H}), 3.36$ (br d, $J 13.5 \mathrm{~Hz}, 1 \mathrm{H}), 3.63(\mathrm{~s}, 3 \mathrm{H}), 3.74(\mathrm{dt}$, $J 2.6$ and $10.6 \mathrm{~Hz}, 1 \mathrm{H}), 3.81(\mathrm{~d}, J 9.9 \mathrm{~Hz}, 1 \mathrm{H}), 7.18-7.25$ (m, 2H), 7.25-7.35 (m, 3H); $\left.{ }^{13} \mathrm{C} \mathrm{NMR} \mathrm{(75.5} \mathrm{MHz;} \mathrm{CD}_{3} \mathrm{OD}\right)$ $\delta 22.8,23.4,27.7,46.7,53.4,55.3,59.2,129.6,129.7$, 130.4, 135.2, 173.3.

\section{Acknowledgments}

The authors wish to acknowledge FINEP, FAPESP, and $\mathrm{CNPq}$ for financial support and fellowships. 


\section{References}

1. a) Overman, L. E.; Ricca, D. J. In Comprehensive Organic Chemistry, Trost, B. M.; Fleming, I., Eds; Pergamon Press: Oxford, 1991, vol. 2, p. 1007; b) Pilli, R. A.; Russowsky, D. Trends in Org. Chem. 1997, 6, 101; c) Arend, M.; Westermann, B.; Risch, N. Angew. Chem. Int. Ed. Engl. 1998, 37, 1045; d) Speckamp, W. N.; Moolenaar, J. M. Tetrahedron 2000, 56, 3817.

2. Evans, D. A.; Nelson, J. V.; Taber, T. R. in Topics in Stereochemistry, Allinger, N. L., Eliel, E. L., Wilen, S. H., Eds, John Wiley \& Sons, 1982, vol 3, p. 1.

3. a) Hiemstra, H.; Speckamp, W. N. In Comprehensive Organic Synthesis, Trost, B. M.; Fleming, I., Eds., Pergamon Press: Oxford 1991, vol. 2, p. 1047; b) de Koning, H.; Speckamp, W. N. In Stereoselective Synthesis, Helmchen, G.; Hoffmann, R. W.; Mulzer, J.; Schaumann, E., Eds., Houben-Weyl 1996, vol E21, p. 1953.

4. a) Nagao, Y.; Daí, W-M.; Ochiai, M. Tetrahedron Lett. 1988, 29, 6133; b) Arenz, T.; Frauenrath, H.; Raabe, G.; Zorn, M. Liebigs Ann. Chem. 1994, 931.

5. Fuentes, L. M.; Shinkai, I.; Salzmann, T. N. J. Am.Chem. Soc. 1986, 108, 4675.

6. a) Nagao, Y.; Daí, W-M.; Ochiai, M.; Tsukagoshi, S.; Fujita, E. J. Am. Chem. Soc. 1988, 110, 289; b) Nagao, Y.; Daí, W-M.; Ochiai, M.; Tsukagoshi, S.; Fujita, E.; J. Org. Chem. 1990, 55, 1148; c) Nagao, Y.; Kumagai, T.; Nagase, Y.; Tamai, S.; Inoue, Y.; Shiro, M. J. Org. Chem. 1992, 57, 4232.

7. a) Evans, D. A.; Urpi, F.; Somers, T. C.; Clark, J. S.; Bilodeau, M. T. J. Am. Chem. Soc. 1990, 112, 8215; b) For a preliminary account of our work on the addition of titanium enolates of $\mathrm{N}$-propionyl oxazolidin-2-ones to $N$-carboalkoxy- $\alpha$-methoxy pyrrolidine and piperidine, see Pilli, R. A.; Alves, C. F.; Böckelmann, M. A.; Mascarenhas, Y. P.; Nery, J. G.; Vencato, I. Tetrahedron Lett. 1999, 40, 2891; c) As this work was about to be concluded, a communication on the addition of the titanium(IV) enolate of $\mathrm{N}$-phenylacetyl oxazolidin2-ones to $N$-carbomethoxy- $\alpha$-methoxypyrrolidine, piperidine and -tetrahydroazepine appeared: Matsumura, Y.; Kanda, Y.; Shirai, K.; Onomura, O.; Maki, T. Org. Lett. 1999, 2, 175; d) Matsumura, Y.; Kanda, Y.; Shirai, J.; Onomura, O.; Maki, T. Tetrahedron 2000, 56, 7411.

8. For the utilization of this methodology in the stereoselective preparation of alkaloids, see: Pilli, R. A.; Russowsky, D. J. Org. Chem. 1996, 61, 3187.

9. a) Moody, C. J.; Taylor, R. J. J. Chem. Soc. Perkin Trans I 1989, 721; b) Speckamp, W. N.; Hubert, J. C.; Wumberg, J. B. P. A. Tetrahedron 1975, 31, 1437.

10. Evans, D. A.; Bartroli, J.; Shih, T. L. J. Am. Chem. Soc. 1981, 103, 2127.
11. Analyses of the ${ }^{1} \mathrm{H}$ - and ${ }^{13} \mathrm{C}$ NMR spectra at room temperature of the adducts were precluded due to the presence of the corresponding rotamers. NMR analyses above room temperature restored baseline resolution allowing determination of the diastereoisomeric ratio.

12. Freshly prepared $n-\mathrm{Bu}_{2} \mathrm{BOTf}$ is required to reproduce yields and avoid partial nitrogen deprotection due to the presence of trace amounts of triflic acid.

13. Morley, C.; Knight, D. W.; Share, A. C. J. Chem. Soc. Parkin Trans 1 1994, 2903.

14. Patrick, K. S.; Caldwell, R. W.; Ferris, R. M.; Breese, G. R. J. Pharmacol. Exp. Ther. 1987, 241, 152.

15. For racemic syntheses of metilphenidate see, inter alia: a) Dias, L. C., Fernandes, A. M. A. P., Synth. Commun. 2000, 30, 1311. For asymmetric syntheses, see: b) Prashad, M.; Har, D.; Ropic, O.; Blacklock, T. J.; Giannousis, P. Tetrahedron: Asymmetry 1998, 9, 2133; c) Faulconbridge, S.; Zavareh, H.; Evans, G.; Langston, M. PCT Int. Appl. Chem. Abstr. 1998, 129, 67705; d) Langston, M.; Zavareh, H. PCT Int. Appl. Chem. Abstr. 1997, 127, 205477; e) Zavareh, H. PCT Int. Appl. Chem. Abtr. 1997, 127, 278144; f) Thai, D. L.; Sapko, M. T.; Reiter, C. T.; Bierer, D. E.; Perel, J. M. J. Med. Chem. 1998, 41, 591; g) Prashad, M.; Kim, H.; Lu, Y.; Har, D.; Repic, O.; Blacklock, T. J.; Giannousis, P. J. Org. Chem. 1999, 64, 1750; h) Davies, H. M. L.; Hansen, T.; Hopper, D. W.; Panaro, S. A. J. Am. Chem. Soc. 1999, 121, 6509; i) Axten, J. M.; Ivy, R.; Krim. L.; Winkler, J. D. J. Am. Chem. Soc. 1999, 121, 6511.

16. Gainetdinov, R. R.; Wetsel, W. C.; Jones, S. R.; Levin, E. D.; Jaber, M.; Caron, M. G. Science 1999, 283, 397.

17. Seebach, D.; Prelog, V. Angew. Chem. Int. Ed. Engl. 1982, 21, 654.

18. Perrin, D. P.; Armarego, W. L. F.; Perrin, D. R. Purification of Laboratory Chemicals, Pergamon Press, Oxford, $2^{\text {nd }}$ Edition, 1985.

19. Ager, D. J.; Allen, D. R.; Scaad, D. R. Synthesis 1996, 1283 .

20. a) Gage, J. R.; Evans, D. A. Org. Synth. 1989, 68, 83; b) Evans, D. A.; Britton, T. C.; Dorow, R. L.; Dellaria, J. F. Tetrahedron 1988, 44, 5525.

21. Shono, T.; Matsumura, Y.; Tsubata, K.; Org. Synth. 1985, 63, 206.

22. Rometsch, R. US. Patent 2,957,880, October 25, 1960.

Received: January 24, 2001 Published on the web: August 15, 2001

FAPESP helped in meeting the publication costs of this article. 